\title{
Challenges for Brain Repair: Insights from Adult Neurogenesis in Birds and Mammals
}

\author{
Fiona Doetscha Constance Scharff b,c \\ a Department of Molecular and Cellular Biology, Harvard University, Cambridge, Mass, USA, \\ bLaboratory of Animal Behavior, The Rockefeller University, New York, N.Y., USA, \\ cMax Planck Institute for Molecular Genetics, Berlin, Germany
}

\section{Key Words}

Birds $\cdot$ Mice $\cdot$ Adult neurogenesis $\cdot$ Regeneration $\cdot$ Stem cells

\begin{abstract}
Adult neurogenesis is a widespread phenomenon occurring in many species, including humans. The functional and therapeutic implications of this form of brain plasticity are now beginning to be realized. Comparative approaches to adult neurogenesis will yield important clues about brain repair. Here, we compare adult neurogenesis in birds and mammals. We review recent studies on the glial identity of stem cells that generate new neurons, the different modes of migration used by the newly generated neurons to reach their destinations, and how these systems respond to experimentally induced cell death. We integrate these findings to address how comparative analysis at the molecular level might be used for brain repair.
\end{abstract}

Copyright $\odot 2002$ S. Karger AG, Basel

\section{Introduction}

Neurogenesis is a large-scale developmental phenomenon that, on a smaller scale, persists throughout adulthood in a wide range of species spanning the phylogenetic

\section{KARGER}

Fax +4161306 1234 E-Mail karger@karger.ch www.karger.com

\section{(C) 2002 S. Karger AG, Basel}

Accessible online at: www. karger.com/journals/bbe tree, from insects to humans [Polenov and Chetverukhin, 1993; Cayre et al., 1996; Alvarez-Buylla and Kirn, 1997; Goldman, 1998; Gould et al., 1999a; Marcus et al., 1999; Schmidt and Harzsch, 2000; Font et al., 2001; Zupanc, 2001]. Both in embryogenesis and in adulthood, and across many species, similarities exist regarding the site of neuronal birth, identity of stem cells, factors regulating precursor proliferation, and the migration and differentiation of neurons. However, important differences also exist among species in the spatial distribution of adultgenerated neurons, in their mode of migration, and phenotypic diversity. Studying the commonalities and differences of neurogenesis along the developmental and phylogenetic continuum promises to yield clues about the basic biology of adult neurogenesis and, therefore, also about its potential for brain repair. In this review, we will compare naturally occurring adult neurogenesis in avian and mammalian classes and how these systems respond to experimentally induced cell death. We will also discuss recent concepts emerging from developmental studies to speculate on future paths towards regeneration of adult brains.

\section{Similar Origins but Different Destinations}

As during embryogenesis, adult neurogenesis occurs in regions adjacent to the ventricles, in birds in the ventricular zone (VZ) [Goldman and Nottebohm, 1983; Alvarez-
Constance Scharff, $\mathrm{PhD}$

Max Planck Institute for Molecular Genetics, Ihnestr. 73, D-14195 Berlin (Germany)

Tel. +4930 8413 1214, Fax +49 308413 1383, E-Mail scharff@molgen.mpg.de

Fiona Doetsch, $\mathrm{PhD}$

Tel. +1 617495 9247, Fax +1 617495 1819, E-Mail doetsch@fas.harvard.edu 
Fig. 1. Sagittal schematic overview of neurogenesis in the adult rodent and avian brain. A In mice, high levels of neurogenesis occur in the subventricular zone (SVZ; orange) and the hippocampus (HP), where most neurons are incorporated into the dentate gyrus (red). Neuroblasts born throughout the SVZ of the lateral wall of the lateral ventricle (LV) migrate along the rostral migratory stream (RMS) to the olfactory bulb (OB), where they differentiate into inhibitory interneurons (red dots). The cerebellum (CB) does not appear to incorporate new neurons in adulthood. B In birds, new neurons are born in the ventricular zone (orange) of the lateral ventricle (LV). From there, they disperse widely and differentiate into neurons throughout many regions of the forebrain (red dots). Particularly high levels of neuronal incorporation occur in the lobus parolfactorius (LPO), which forms part of the avian basal ganglia. Nucleus HVC of the circuit that controls song learning and production also receives a higher proportion of new neurons than surrounding areas. HVC sends projections to Area X (X) within LPO and also towards the robust nucleus of the archistriatum (RA), which is pre-motor in nature. No new neurons incorporate into either the adult RA or the cerebellum.

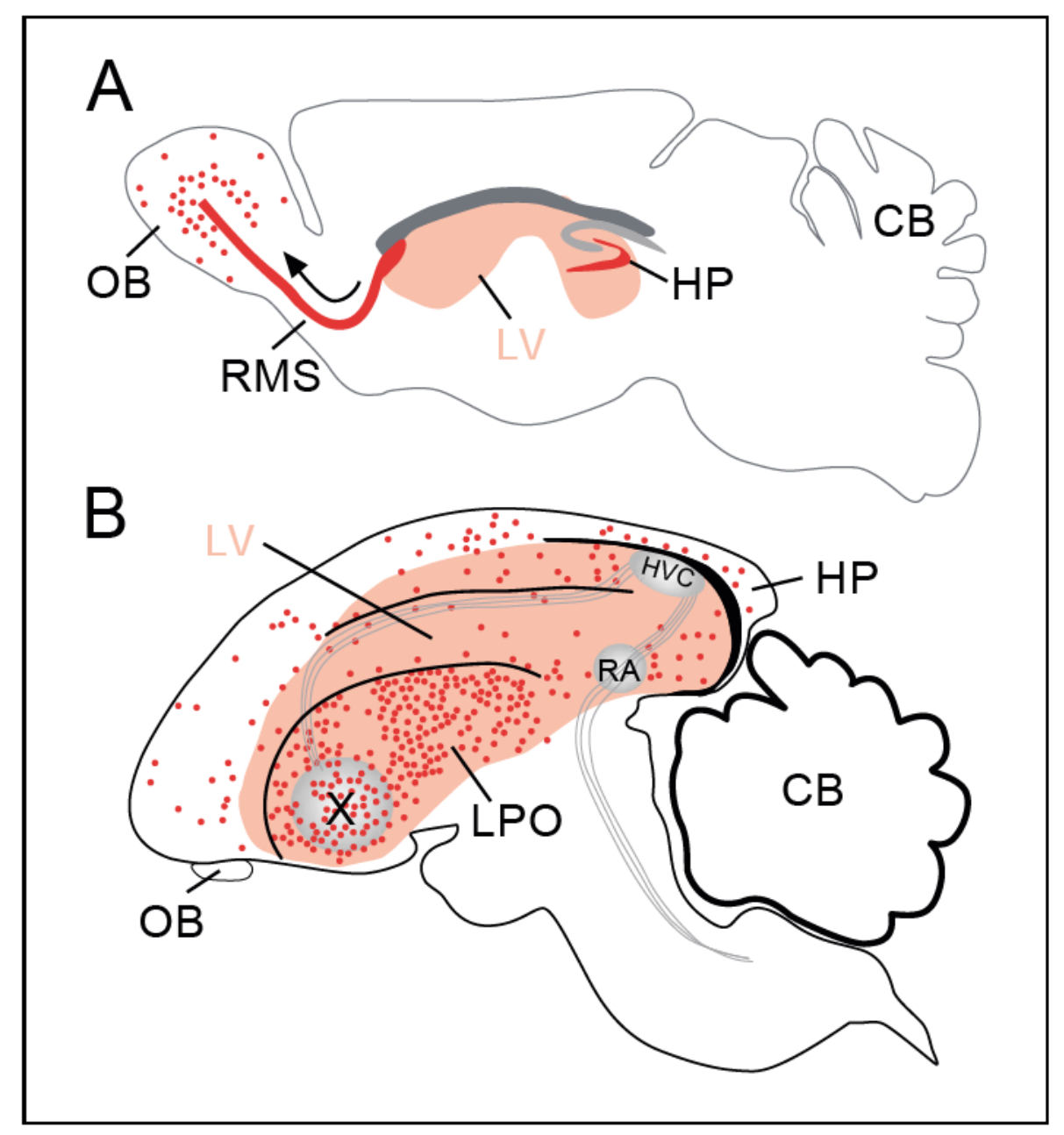

Buylla and Nottebohm, 1988; Alvarez-Buylla et al., 1998], and in mice in the subventricular zone (SVZ) [García-Verdugo et al., 1998] (fig. 1). Specialized cases are the rodent hippocampal neurogenic subgranular zone, which is originally derived from the SVZ, but in adults is no longer contiguous with the ventricle [Altman and Das, 1965; Altman and Gopal, 1965; Altman and Bayer, 1990a, b]; and neurogenic zones near the midline in the molecular layer of various subdivisions of the cerebellum in adult teleost fish [Zupanc, 2001]. Precursors in these germinal regions divide to give rise to neurons that migrate to their ultimate destinations where they differentiate into mature neurons of distinct phenotypes.

Despite a common origin, neurons born in adulthood disperse into different brain regions in different species. In cold-blooded vertebrates and birds, new neurons incorporate into many regions throughout the adult telencephalon [Alvarez-Buylla and Nottebohm, 1988; see also reviews by Font et al., 2001; and Zupanc, 2001], whereas only the adult olfactory bulb and hippocampus are now widely acknowledged to incorporate neurons in all mammals studied so far [Altman and Das, 1965; Altman, 1969; Gould and Cameron, 1996; Gould et al., 1997; Eriksson et al., 1998; Gage et al., 1998; Gould et al., 1999a; Kornack and Rakic, 1999, 2001a; Rietze et al., 2000; Pencea et al., 2001a], despite initial reports to the contrary [Rakic, 1985; Eckenhoff and Rakic, 1988] (fig. 1). Outside of these neurogenic regions, low levels of ongoing adult neurogenesis might occur, but evidence is contradictory. In rodents and cats, few or no adult born neurons have been found in the neocortex [Altman, 1963; Kaplan, 1981; Magavi et al., 2000], whereas in primates reports vary from no to considerable amounts of adult neurogenesis [Gould et al., 1999b; Gross, 2000; Nowakowski and Hayes, 2000; Kornack and Rakic, 2001b]. 


\section{Different Modes of Migration Serve Different Destinations}

During brain histogenesis, newly generated neurons utilize different modes of migration to reach their final location: radial glial-guided migration, somal translocation, and tangential migration. During radial glial-guided migration, neurons migrate away from their birthplace along the fibers of radial glia [Rakic, 1972, 1995; Hatten, 1993], whose cell bodies are located in the VZ and whose processes span the width of the developing brain and end on the pial surface [Schmechel and Rakic, 1979a; Gadisseux et al., 1989]. In somal translocation, a neuron moves towards the surface of the brain without radial glial guidance through its own radial process that is in contact with the surface of the brain [Morest, 1970; Miyata et al., 2001; Nadarajah et al., 2001]. Radial migration has been proposed to be important for the formation of functional radial units in the brain [Gray et al., 1988; Rakic, 1988; Noctor et al., 2001]. In contrast, tangential migration allows for the dispersal of neurons along pathways perpendicular to and not 'served' by radial glia, enabling new neurons born in similar neighborhoods (and, therefore, possibly with similar characteristics) to disperse widely throughout the brain [Parnavelas, 2000]. The different spatial distribution of adult-formed neurons in mice and birds (restricted in mice and widespread in birds) is likely due to the fact that radial glia are maintained throughout adulthood in birds, but not in mice [Schmechel and Rakic, 1979a, b; Alvarez-Buylla et al., 1988]. In contrast, tangential migration persists in the germinal regions of all adult vertebrates where it has been investigated [Doetsch and Alvarez-Buylla, 1996; Lois et al., 1996; Scharff et al., 1998; Kornack and Rakic, 2001].

\section{Universal Web of New Neurons}

In rodents, the adult germinal SVZ, which generates neurons destined for the olfactory bulb, is a thin layer of cells adjacent to the lateral wall of the lateral ventricle. It has been suggested that the SVZ is compartmentalized into a small anterior neurogenic region, the SVZa, and a large posterior expanse, which is gliogenic or in which dividing cells undergo abortive death after mitosis [Smart, 1961; Privat and Leblond, 1972; Morshead and Van der Kooy, 1992; Luskin, 1993; Levison and Goldman, 1993]. However, whole mount preparations that expose the entire surface of the lateral ventricular wall reveal that the length of the SVZ is traversed by an extensive network of chains of migrating immature neurons (called neuroblasts) stained with an antibody against a polysialylated neural cell adhesion molecule, PSA-NCAM (fig. 2A, F) [Doetsch and Alvarez-Buylla, 1996]. Newly generated neurons even from caudal regions of the SVZ (at the level of the posterior hippocampus) migrate $5-8 \mathrm{~mm}$ rostrally to reach the olfactory bulb where they differentiate into inhibitory interneurons. This was shown by transplantation of genetically labeled SVZ tissue and by focal labeling of endogenous SVZ cells with the lipophilic dye 1,1'-dioctadecyl-3,3,3' $3^{\prime}{ }^{\prime}$-tetramethylindocarbocyanine perchlorate (DiI) [Lois and Alvarez-Buylla, 1994; Doetsch and Alvarez-Buylla, 1996]. This tangential migration occurs through homophilic interactions, without the need for radial glia [Lois et al., 1996; Peretto et al., 1997; Wichterle et al., 1997].

Frogs, geckos, alligators, songbirds (fig. 2C, E), rats, cats (fig. 2G), and primates (squirrel monkey and macaque; fig. $2 \mathrm{H}$ ) all have pathways of tangentially migrating neurons in the ventricular wall, although the destinations of the newly generated neurons have not yet been mapped in each species [Scharff et al., 1998, F. Doetsch and A. Alvarez-Buylla, unpubl. obs.].

In songbirds, focal injections of the lipophilic dye DiI or the proliferation marker bromodeoxyuridine (BrdU) into the most actively proliferating regions in the VZ, called hot-spots [Alvarez-Buylla et al., 1990], indicate that, as in mice, the direction of neuronal migration is rostral, but that in addition, there is a stream of migrating neurons coursing ventro-caudally underneath the caudal telencephalon (fig. 2C). In contrast to mice, the major destination of the rostrally migrating PSA-NCAM-positive neurons is not the olfactory bulb which is relatively small and not considered an important sensory processing center in songbirds. Instead, many of these cells likely end up in the avian basal ganglia, the lobus parolfactorius (fig. 1B), which incorporates a disproportionate number of new neurons in adult canaries [Alvarez-Buylla et al., 1994]. It is not yet clear how radial and tangential migration are integrated in the adult bird VZ. Newly generated neurons may sequentially use both tangential and radial modes of migration, or, alternatively, individual neurons may be limited to one type of migration. This would be in contrast to chick development, where radial migration is the prominent early form of migration, followed by a switch to more tangential dispersal [Gray et al., 1990]. In adult songbirds, new neurons (labeled with BrdU and an early neuronal marker, $\mathrm{Hu}$ ) are first observed migrating away from the $\mathrm{VZ}$ along radial glia 4 days after their birth, leading to the belief that new cells committed to become neurons 'wait' 

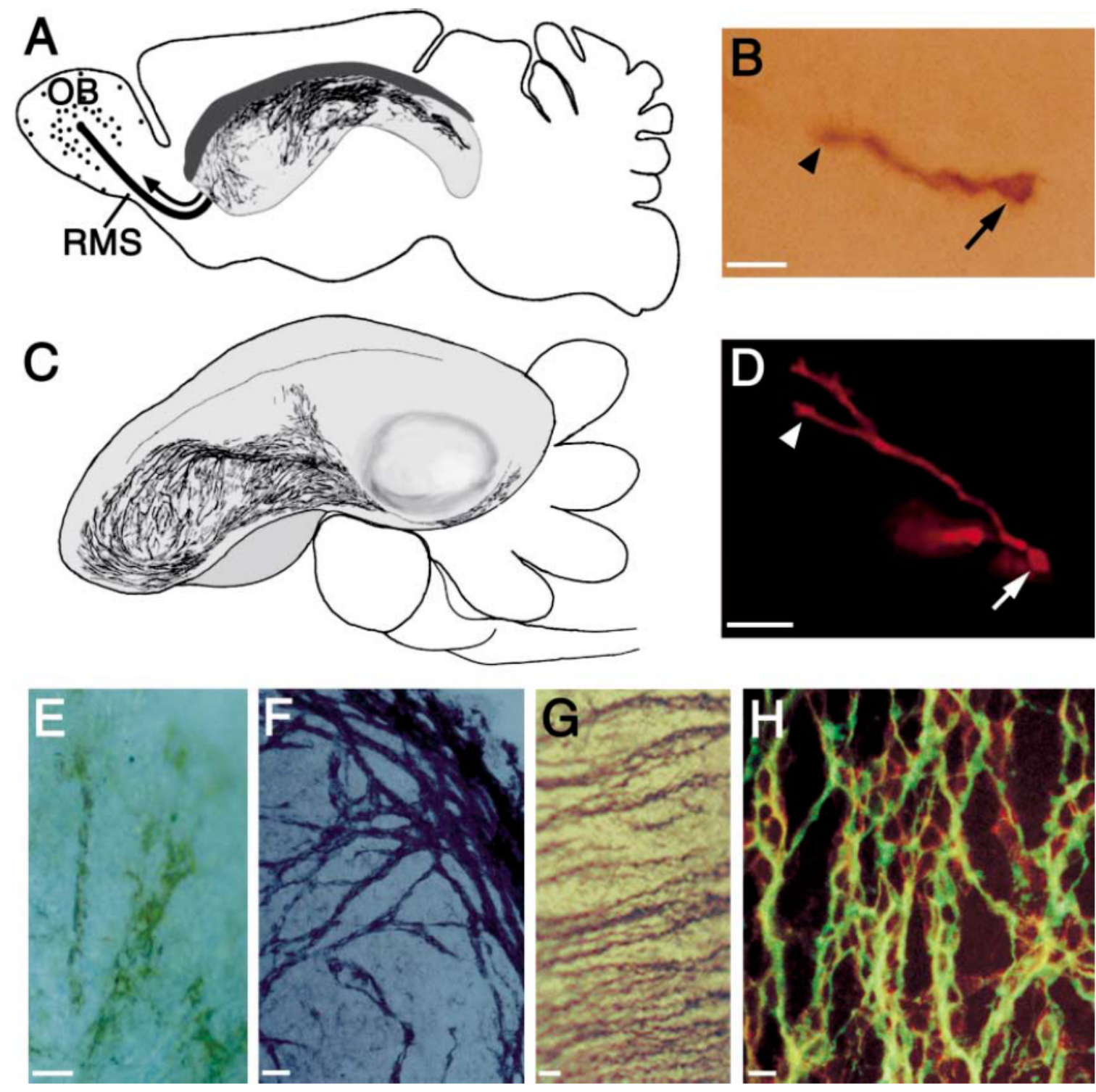

Fig. 2. Universal web of neurons: A network of newly generated neurons is present throughout the lateral ventricular wall of all vertebrates. Schematic sagittal sections of (A) the adult mouse and (C) bird brain showing camera lucida drawings of the network of chains stained in whole-mounts with an antibody against the polysialylated form of neural cell adhesion molecule, PSA-NCAM. For better visualization, the drawing of the lateral ventricular wall with the migrating chains in mice (A) is shown slightly larger than the rest of the brain. (Modified after Doetsch and Alvarez-Buylla, 1996.) Mi- grating neurons have small $(5 \mu \mathrm{m})$ fusiform cell bodies (arrows) and a characteristic long leading process (arrowheads) with one or multiple growth cones labeled with a retrovirus encoding the marker gene alkaline phosphatase (mouse) (B) and with the lipophilic dye DiI (bird) (D). Chains of migrating PSA-NCAM-stained neurons appear remarkably similar in adult birds (E, brown staining), mice (F, purple staining), cats (G, brown staining) and (H) primates (macaque) (double labeled with both PSA-NCAM (red) and the neuronal marker TuJ1 (green) (H). Scale bars: B, D, $20 \mu \mathrm{m}$; E-G, $50 \mu \mathrm{m}, \mathbf{H}, 5 \mu \mathrm{m}$. in the VZ before initiating radial migration [Barami et al., 1995]. However, after focal injection of BrdU into the VZ of adult songbirds, we have observed 1-day-old $\mathrm{Hu}+/$ BrdU+ neurons, with a morphology typical of tangentially migrating neurons [Scharff et al., 1998] distant from the site of injection. We suggest that $\mathrm{Hu}+$ new neurons are not simply 'waiting' in the VZ, but undergo homophilic tangential migration before turning into the brain parenchyma using radial glia as further guideposts. Further research needs to directly address this issue.

Another area of the songbird brain that receives a substantial contribution of new neurons in adulthood is the 


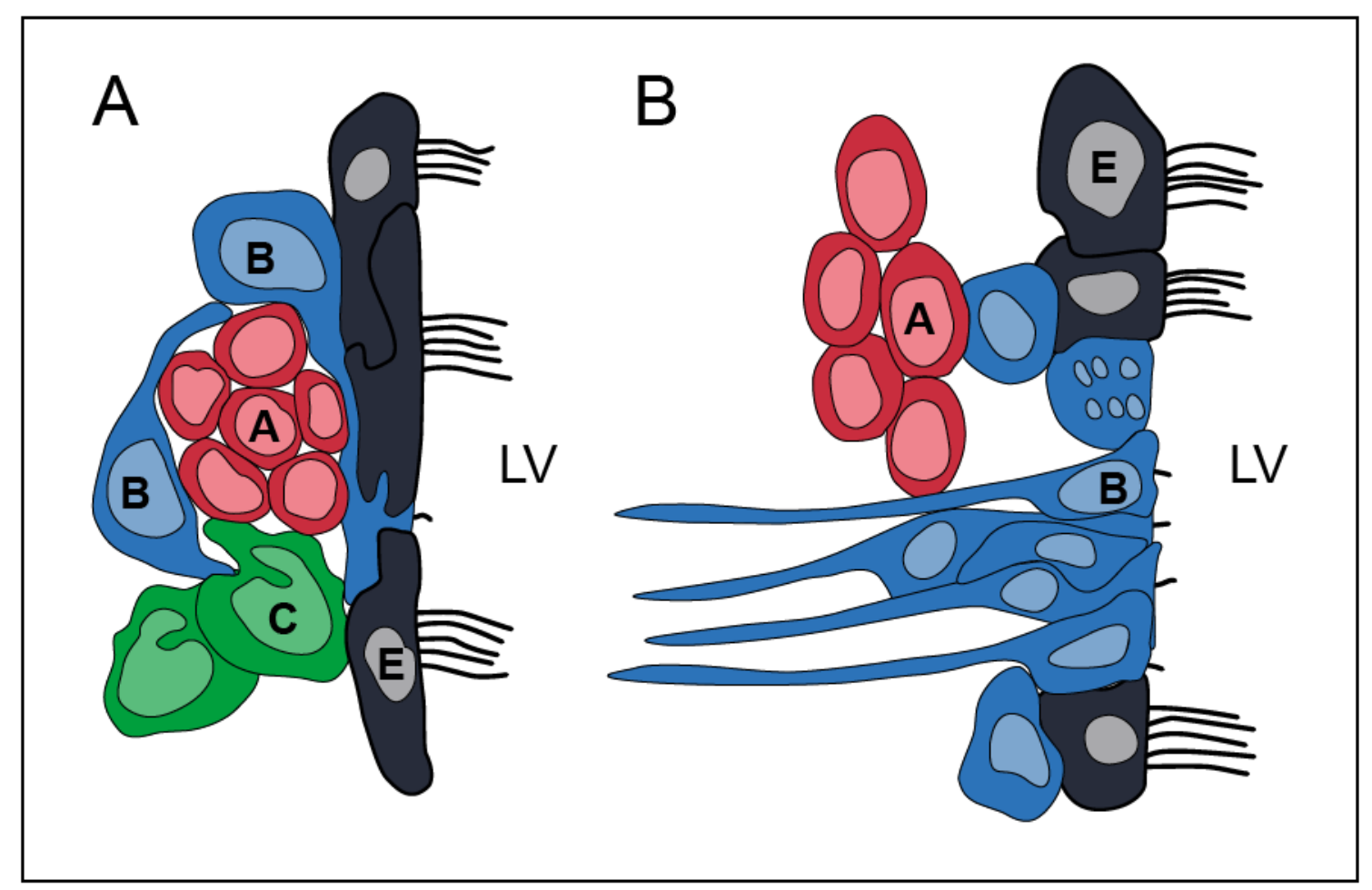

Fig. 3. Cell types of the adult mouse (A) and songbird (B) germinal regions. A In the adult mouse SVZ, multi-ciliated ependymal cells (type E, grey) line the lateral ventricle. This lining is occasionally broken by the process of an SVZ astrocyte (type B cell, blue) that extends a process and contacts the ventricle. These type $B$ cells often have a unique cilium with a $9+0$ internal structure. Chains of neuroblasts (type A cells, red, cut in cross-section) travel through tunnels formed by the processes of SVZ astrocytes. Clusters of rapidly dividing transit amplifying cells (type $\mathrm{C}$, green) are adjacent to the chains of neuroblasts. (Modified after Doetsch et al., 1997.) SVZ astrocytes are stem cells in this region and generate type $\mathrm{C}$ cells which, in turn, divide to give rise to the neuroblasts. B In contrast to mice, in songbirds glial cells (type B cells, blue) are frequently in contact with the lateral ventricle. They have a unique short cilium with an $8+0$ or $9+0$ microtubule structure. They undergo interkinetic nuclear migration, and mitosis occurs at the ventricular surface. Many of these glial cells have a radial glial phenotype. Migrating neuroblasts (type A cells, red) are organized in chains that run parallel to the ventricle. This schematic view shows a chain cut in cross-section, with the ventricle (LV) to the right. As in mice, multi-ciliated ependymal cells (type E, grey) also line the ventricle. (Modified after Alvarez-Buylla et al., 1998.) song control nucleus HVC (acronym used as proper name) which lies dorsocaudally to the ventricular network of tangentially migrating new neurons (fig. 1B). Curiously, in spite of the significant recruitment of new neurons into adult HVC, no clear paths of tangentially migrating neuron chains are observed in its vicinity [Scharff et al., 1998]. New neurons may reach the adult HVC via migration along radial glia, yet radial glia are also conspicuously rare in HVC [see fig. 10A in Holzenberger et al., 1997]. This raises the possibility that new HVC neurons originate in the directly adjacent VZ. However, short-survivalBrdU labeling studies show only very few dividing cells in the VZ immediately overlying HVC. Thus, the origin and route of arrival for $\mathrm{HVC}$ neurons remains enigmatic.

\section{Stem Cells in the Adult Brain}

\section{Cell Types and Architecture of the Adult Mouse SVZ}

The SVZ of adult rodents comprises four main cell types (fig. 3A): neuroblasts (also called type A cells, red), SVZ astrocytes (type B cells, blue), transit amplifying cells (type $\mathrm{C}$ cells, green), and ependymal cells which line the walls of the ventricle (type E cells, gray). These cells can be unambiguously identified by a combination of their distinct ultrastructural characteristics, molecular markers, and proliferative potential, some of which are listed in table 1 [Doetsch et al., 1997, 1999a]. In particular, PSANCAM is only expressed by neuroblasts, whereas a monoclonal antibody for GFAP only labels SVZ astrocytes and not ependymal cells in this region [F. Doetsch, unpubl. 
Table 1. Characteristics of adult mouse subventricular zone cells

\begin{tabular}{|c|c|c|c|c|c|}
\hline $\begin{array}{l}\text { Label or ultrastructural } \\
\text { feature }\end{array}$ & $\begin{array}{l}\text { Neuroblast } \\
\text { (type A cell) }\end{array}$ & $\begin{array}{l}\text { SVZ astrocyte } \\
\text { (type B cell) }\end{array}$ & $\begin{array}{l}\text { Transit amplifying } \\
\text { cell (type } \mathrm{C} \text { cell) }\end{array}$ & $\begin{array}{l}\text { Ependymal cell } \\
\text { (type E cell) }\end{array}$ & References \\
\hline PSA-NCAM & + & - & - & - & Doetsch et al., 1997 \\
\hline TuJ1 & + & - & - & - & Doetsch et al., 1997 \\
\hline GFAP (monoclonal) & - & + & - & - & $\begin{array}{l}\text { F. Doetsch, } \\
\text { unpublished } \\
\text { observations }\end{array}$ \\
\hline GFAP (polyclonal) & - & + & - & + & Doetsch et al., 1997 \\
\hline $\mathrm{mCD} 24$ & + & - & not determined & + & Calaora et al., 1996 \\
\hline Vimentin & - & + & - & + & Doetsch et al., 1997 \\
\hline Nestin & + & + & + & + & Doetsch et al., 1997 \\
\hline BrdU or $\left[{ }^{3} \mathrm{H}\right]$ thymidine & + & + & + & - & $\begin{array}{l}\text { Doetsch et al., 1997; } \\
\text { Doetsch et al 1999a, b }\end{array}$ \\
\hline Cytoplasm & dark, scant & light & intermediate & very light & Doetsch et al., 1997 \\
\hline Nuclei & $\begin{array}{l}\text { elongated, occasion- } \\
\text { ally invaginated }\end{array}$ & $\begin{array}{l}\text { irregular, frequently } \\
\text { invaginated }\end{array}$ & $\begin{array}{l}\text { large spherical, } \\
\text { deeply invaginated }\end{array}$ & $\begin{array}{l}\text { spherical, } \\
\text { not invaginated }\end{array}$ & Doetsch et al., 1997 \\
\hline Intermediate filaments & - & + & - & + & Doetsch et al., 1997 \\
\hline Lipid droplets & - & - & - & + & Doetsch et al., 1997 \\
\hline Cilium & - & $\begin{array}{l}\text { single, } 9+0 \text { internal } \\
\text { microtubule } \\
\text { structure }\end{array}$ & - & $\begin{array}{l}\text { multiple, } 9+2 \\
\text { microtubule } \\
\text { structure }\end{array}$ & $\begin{array}{l}\text { Doetsch et al., 1997; } \\
\text { Doetsch et al., 1999b }\end{array}$ \\
\hline Contacts & $\mathrm{A}-\mathrm{A}, \mathrm{A}-\mathrm{C}$ & B-B, B-E & C-C, C-A & E-E, E-B & Doetsch et al., 1997 \\
\hline
\end{tabular}

BrdU = 5-bromo-2'-deoxyuridine; GFAP = glial fibrillary acidic protein; PSA-NCAM = polysialylated neural cell adhesion molecule.

obs.], in contrast to a polyclonal antibody against GFAP that labels both ependymal cells and SVZ astrocytes.

\section{Glial Cells as Stem Cells in Adult Mice}

Neural stem cells can be cultured from the adult brain as adherent cultures or non-adherent cultures in the presence of growth factors [Gage, 2000]. These cells exhibit the two fundamental properties of stem cells - they undergo self-renewal and are multipotent, that is, they can differentiate into neurons and glia. Multipotent neural stem cells can be isolated from the adult mouse SVZ by dissociating and culturing single SVZ cells in the presence of epidermal growth factor (EGF) [Morshead et al., 1994], basic fibroblast growth factor (bFGF) [Gritti et al., 1996], or both [Weiss et al., 1996; Gritti et al., 1999; Rietze et al., 2001]. A subset of these cells divide in response to these growth factors and generate floating clusters of cells called neurospheres. Neurospheres can be passaged to generate secondary neurospheres (demonstrating self-renewal) and are multipotent, i.e. they can generate neurons, astrocytes, and oligodendrocytes upon removal of the growth factors [Reynolds and Weiss, 1992]. However, multipotency and self-renewal capacity might not be limited to the primary in vivo stem cells (primary is defined here as the first cell in the lineage), and, therefore, multiple cell types could give rise to neurospheres.

Stem cell candidates in the adult SVZ have recently been identified. Surprisingly, they are SVZ astrocytes, which exhibit features of differentiated glial cells. There are four independent, but complimentary, lines of evidence that together demonstrate that SVZ astrocytes act as stem cells and generate neurons in this region [Doetsch et al., 1999b]. First, SVZ astrocytes give rise to neurospheres in vitro. This was shown by vitally labeling SVZ astrocytes in vivo with an adenovirus driving expression of green-fluorescent protein (GFP) under the GFAP promoter, which is specific to SVZ astrocytes (table 1). When cultured, the vitally labeled astrocytes gave rise to GFPpositive neurospheres. Second, the progeny of SVZ astrocytes migrate and differentiate into granule and periglomerular olfactory bulb neurons. This was demonstrated via in vivo astrocyte-specific infection with a retrovirus carrying the marker gene for alkaline phosphatase. The selective infection of astrocytes was achieved by using a transgenic mouse in which only GFAP-expressing cells carry the receptor for an avian retrovirus, RCAS [Holland and Varmus, 1998]. Thus, only dividing GFAP-positive cells (i.e., only astrocytes in the SVZ) can be infected with 
RCAS. Third, consistent with their being stem cells, SVZ astrocytes are the only label-retaining cells (LRCs) in this region. Stem cells are often relatively quiescent, and can only be labeled with prolonged administration of proliferation markers, such as BrdU or $\left[{ }^{3} \mathrm{H}\right]$ thymidine. LRCs remain labeled long after administration of the label is stopped and are thought to be the result of an asymmetric self-renewing division of a stem cell [Potten and Morris, 1988; Sprangrude et al., 1988; Cotsarelis et al., 1989]. In contrast, rapidly dividing cells that are initially labeled will dilute their label with continuous divisions, while their progeny will migrate away from the germinal region to their site of terminal differentiation. One month after termination of long-term intraventricular infusions of $\left[{ }^{3} \mathrm{H}\right]$ thymidine, ultrastructural analysis revealed that all labeled cells were SVZ astrocytes. In addition, a retrovirus encoding $\beta$-galactosidase was also used as a label. Again, all cells labeled one month after infection were SVZ astrocytes.

Fourth, SVZ astrocytes are able to regenerate the entire SVZ. When the SVZ is destroyed by elimination of all neuroblasts and transit amplifying type $C$ cells by intracerebral infusion of an anti-mitotic drug, only ependymal cells and SVZ astrocytes remain [Doetsch et al., 1999a, b]. Remarkably, after anti-mitotic treatment ceases, the SVZ regenerates simultaneously over the entire ventricle. This regeneration process is initiated by the SVZ astrocytes that are the first and only cells to start dividing. They give rise to type $\mathrm{C}$ cells that, in turn, generate the neuroblasts. This was shown by pulse-labeling experiments in vivo and time-lapse photography of single GFP-labeled astrocytes in whole-mount explants in vitro. Thus, SVZ astrocytes are neural stem cells in this region under both normal conditions and during regeneration. In the dentate gyrus, GFAP+ astrocytes with similar morphology to those in the SVZ have recently also been shown to be neuronal precursors [Seri et al., 2001].

\section{Ependymal Cells as Stem Cells?}

Ependymal cells have been suggested to be the primary neural stem cells in the SVZ, giving rise to neurospheres in vitro, to retain label in vivo, and to generate olfactory bulb neurons [Johansson et al., 1999]. However, the LRCs were identified based only on anatomical location, without double immunostaining for ependymal cell markers or electron microscopic analysis. Without these methods, it is possible to confuse ependymal cells and SVZ astrocytes, particularly as sometimes a thin ependymal cell process is all that separates an SVZ cell from the ventricle. In our hands, no labeled ependymal cells (identified by immunostaining with anti-mCD24 antibodies or by electron microscopy) were found in vivo even after two weeks of continuous administration of BrdU or $\left[{ }^{3} \mathrm{H}\right]$ thymidine. Also, during regeneration of the SVZ, when stem cells are actively recruited, no ependymal cells were observed incorporating $\left[{ }^{3} \mathrm{H}\right]$ thymidine at any survival time after anti-mitotic treatment. Johansson et al. [1999] used the lipophilic dye DiI to label ependymal cells in vivo before culturing neurospheres and found DiI-positive neurospheres. However, DiI is easily transferred from one cell to another and will label any cell in contact with the ventricle, including some SVZ astrocytes. Because other groups have not been successful in culturing neurospheres from ependymal cells [Chiasson et al., 1999; Doetsch et al., 1999b; Laywell et al., 2000; Morshead and Van der Kooy, 2001], resolution of the controversy surrounding the stem cell nature of ependymal cells will require additional experiments.

Ependymal cells, however, play an important role in creating an environment that is permissive for neurogenesis. SVZ astrocytes produce bone morphogenic proteins (BMPs) that inhibit neurogenesis in this region. Ependymal cells secrete noggin, an antagonist of BMP signaling, thereby relieving the inhibitory effects of BMPs (Lim et al., 2000). Thus, the interaction between ependymal cells and other SVZ cell types likely creates a niche permissive for adult neurogenesis.

\section{Cell Types and Architecture of the Adult Songbird Ventricular Zone}

As in mice, the adult germinal layer in birds contains ependymal cells $(9+2$ internal microtubule structure), young migrating neurons, and glial cells, some of which have a single cilium $(8+0$ or $9+0$ internal microtubule structure) [Alvarez-Buylla et al., 1998] (fig. 3B). However, there are a number of differences. There is no equivalent to the murine transit amplifying cell (type $C$ cell), and the glial cell-type in birds is not of branched astrocytic morphology, but of radial glial phenotype which maintains an elongated process reaching deep into the brain parenchyma. In addition, the glial cell type in birds is typically in direct contact with the ventricle, whereas in mice the glial cells only occasionally contact the ventricle (fig. 3). Mice and birds are also distinguished by which cells divide in the SVZ/VZ. In birds, only the glial cells divide [AlvarezBuylla et al., 1998], whereas in mice glial cells, transit amplifying cells (type $\mathrm{C}$ cells), and migrating neuroblasts all divide [Doetsch et al., 1997, 1999b]. 
Glial Cells Give Rise to Neurons in Adult Song Birds

In songbirds, radial glia are the likely precursors of adult-generated neurons, as indicated by pulse-labeling studies with $\left[{ }^{3} \mathrm{H}\right]$ thymidine. Shortly after a single injection of $\left[{ }^{3} \mathrm{H}\right]$ thymidine, only radial glia are labeled; at intermediate survival times labeled neurons are seen migrating away from the VZ; and after three or more weeks, labeled differentiated neurons are found throughout the telencephalon [Alvarez-Buylla and Nottebohm, 1988; Alvarez-Buylla et al., 1990]. Further support for the notion that radial glia are neuronal precursors comes from retroviral infection of dividing cells in the $\mathrm{VZ}$ that yields clones containing both radial glia and neurons [Goldman et al., 1996], suggesting that a single radial glial cell gives rise to both glia and neurons.

\section{Glial Cells as Stem Cells Across Phylogeny and Development?}

The finding that glia are stem cells in the adult brain and generate neurons in several species is surprising, given that glia and neurons were thought to derive from different lineages during embryogenesis and that the major wave of gliogenesis occurs after neurogenesis [Levitt et al., 1981; Jacobson, 1991; Alvarez-Buylla et al., 2001]. However, it is becoming increasingly clear that both during embryonic development and in adulthood some types of glia can give rise to neurons. Radial glia have been hypothesized to serve dual functions, acting not only as scaffolding for neuronal migration [Rakic, 1972; Hatten and Mason, 1990], but also as neuronal precursors during brain histogenesis [Frederiksen and McKay, 1988; Gray and Sanes, 1992; Malatesta et al., 2000]. In fact, recent work directly and elegantly demonstrates that radial glia give rise to neurons [Noctor et al., 2001]. When radial glia persist into adulthood, as is the case in birds, both precursor and guide functions are retained [Alvarez-Buylla and Nottebohm, 1988; Alvarez-Buylla et al., 1990]. What remains to be determined is whether radial glia are true self-renewing, multipotent stem cells, both in the embryo and in the adult avian brain.

In mice, radial glia in the cortex transform into astrocytes at the end of development, and this conversion apparently occurs throughout the brain [Schmechel and Rakic, 1979a; Voigt, 1989]. It is an attractive hypothesis that the neurogenic potential of adult SVZ astrocytes is derived from (and preserved through) their origin in embryonic radial glia. Recent experiments have shown that, when neuroepithelial cells are infected with a retrovirus encoding both a marker gene and activated Notch, which is thought to maintain precursors in an undifferen- tiated state, a radial glial fate is promoted. Over time, the infected radial glia then seem to transform into astrocytes, including SVZ astrocytes [Gaiano et al., 2000]. Whether radial glia become $S V Z$ astrocytes in the absence of activated Notch needs to be further explored.

Radial glia comprise a heterogeneous population of cells [Hartfuss et al., 2001] that generate both neuronal and non-neuronal progeny. During embryonic and early postnatal stages, glial cells from multiple brain regions can give rise to both neurons and neurogenic neurospheres [Laywell et al., 2000; Malatesta et al., 2000; Noctor et al., 2001; Skogh et al., 2001; Miyata et al., 2001]. The neurosphere-generating competence exhibited by glial cells becomes restricted to SVZ astrocytes after the second postnatal week [Laywell et al., 2000]. It is possible that extrinsic (inhibitory) region-specific molecular factors cause this restriction, as radial glia transform into astrocytes. Because radial glia also transform into astrocytes in marsupials [Ghooray and Martin, 1993], the neurogenic potential of some astrocytes in the adult central nervous system may be common to all mammals. This scenario, in which radial glia act as neuronal precursors both during development and adulthood in non-mammalian vertebrates, but are transformed into neurogenic astrocytes in adult mammals [Doetsch et al., 1999b; Seri et al., 2001], satisfies developmental and phylogenetic logic.

\section{Phenotype and Turnover of Adult-Generated Neurons}

Adult-born neurons are usually of the phenotype that typically emerges late in development. The particular neuron types vary with species and even different brain regions, and can be interneurons or projection neurons. In the case of adult mammals, new neurons can be local circuit interneurons in the olfactory bulb [Altman, 1969], or local projection neurons in the hippocampus [Stanfield and Trice, 1988; Markakis and Gage, 1999] and primate neocortex [Gould et al., 1999b]. The projection neurons of the olfactory bulb, the mitral and tufted cells, are not generated in adulthood. Rather, two kinds of inhibitory interneurons are generated in the adult olfactory bulb, granule neurons and periglomerular neurons, both of which form dendrodentritic synapses with mitral cells. Both granule and periglomerular neurons are GABAergic, although periglomerular neurons also produce dopamine. In the adult dentate gyrus, newly generated granule neurons project to CA3 as the mossy fiber pathway. Hippocampal granule neurons are excitatory, utilizing glutamate and aspartate as neurotransmitters. In both the dentate gyrus and the olfactory bulb, it is assumed that the newly generated cells adopt the neurotransmitter pheno- 

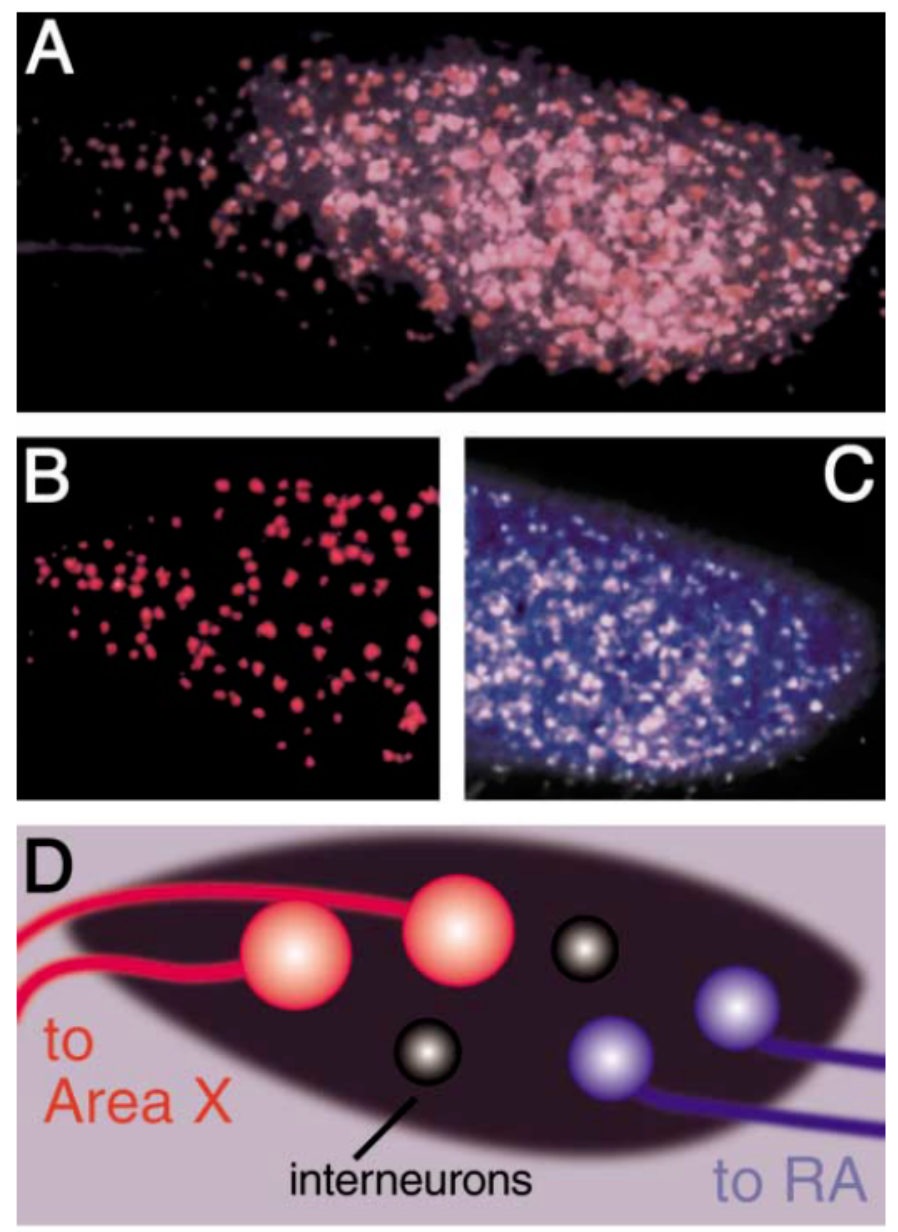

\begin{tabular}{|c|c|c|}
\hline E ABLATION & $\begin{array}{c}\text { NEW } \\
\text { NEURONS } \\
\end{array}$ & SONG \\
\hline in adults & $\begin{array}{c}\text { no } \\
\text { change }\end{array}$ & $\begin{array}{c}\text { no } \\
\text { change }\end{array}$ \\
\hline in adults & & $\begin{array}{c}\text { deteriorates } \\
\text { then } \\
\text { recovers }\end{array}$ \\
\hline & & $\begin{array}{c}\text { develops } \\
\text { abnormally }\end{array}$ \\
\hline
\end{tabular}

Fig. 4. Targeted neuronal death causes compensatory neuronal repair. A HVC contains two intermingled and largely overlapping projection neuron types, $\mathrm{HVC} \rightarrow \mathrm{RA}$ neurons and $\mathrm{HVC} \rightarrow \mathrm{X}$ neurons, shown here in a 50- $\mu \mathrm{m}$-thick sagittal section double-exposed with the appropriate UV filters to show red neurons retrogradely labeled with rhodamine microspheres from Area X (B) and white neurons retrogradely labeled with fluorogold from $\mathrm{RA}(\mathbf{C})$. $\mathrm{HVC} \rightarrow \mathrm{X}$ neurons are larger, but less numerous, than $\mathrm{HVC} \rightarrow \mathrm{RA}$ neurons $(\mathbf{B}, \mathbf{C})$. In addition to these projection neurons, HVC contains interneurons (D). Interneurons and $\mathrm{HVC} \rightarrow \mathrm{RA}$ neurons are generated de novo in adult- type typical of that region. Although recent studies have begun to characterize the maturation of these cells electrophysiologically [Wang et al., 2000; Liu et al., 2000], little is known about the neurotransmitter profiles of the newly generated neurons.

Although neurogenesis occurs throughout the telencephalon of adult birds [Alvarez-Buylla and Kirn, 1997], most knowledge about this phenomenon derives from studies in songbirds, and the identity of newly generated neurons is known for only one brain area, HVC. New local interneurons are incorporated into HVC (fig. 4D), and long-distance projection neurons to a premotor nucleus, the nucleus robustus archistriatalis (RA), are also added to this region; this latter type is called $\mathrm{HVC} \rightarrow \mathrm{RA}$ neuron (fig. 4C, D). A third type of HVC neuron, which projects to the avian basal ganglia, is not generated in adulthood; this type is called HVC $\rightarrow \mathrm{X}$ neuron (fig. 4B, D). New neurons are frequently surrounded by tyrosine hydroxylase (TH)-like immunoreactivity, probably a reflection of the dopaminergic HVC innervation from a midbrain structure, the nucleus tegmentalis pedunculopontinus (TPc) [Paton et al., 1986]. Whether this innervation is specific for the new interneurons or the new projection neurons remains to be seen. GABA does not appear to colocalize with new HVC neurons [Paton et al., 1986]. Beyond this, little is known about the pharmacological and electrophysiological profile of new neurons. However, a number of recent studies using intracellular recording to characterize HVC neurons point towards the feasibility of this endeavor [Dutar et al., 1998, 2000; Kubota and Taniguchi, 1998].

Many of the adult-formed neurons in birds and mammals appear to be transitory populations that are culled within weeks after birth [Cameron et al., 1993; Gould et al., 1999b, c; Kirn et al., 1999; Petreanu and AlvarezBuylla, 2000], although a proportion of those that are

hood, whereas HVC $\rightarrow \mathrm{X}$ neurons are not. E Schematic overview of effect of targeted neuronal death on neurogenesis. Ablation of $\mathrm{HVC} \rightarrow \mathrm{X}$ neurons in adults does not cause compensatory neuron recruitment, and song is not changed. Ablation of $\mathrm{HVC} \rightarrow \mathrm{RA}$ neurons in adults causes song deterioration with subsequent recovery. An increased recruitment of both interneurons and $\mathrm{HVC} \rightarrow \mathrm{RA}$ neurons is observed at the time when song has recovered. Ablation of $\mathrm{HVC} \rightarrow \mathrm{X}$ neurons in juveniles results in abnormal song development and in an increase of interneurons and $\mathrm{HVC} \rightarrow \mathrm{RA}$ neurons, but not $\mathrm{HVC} \rightarrow \mathrm{X}$ neurons. Scale bars, $50 \mu \mathrm{m}$. 
functionally incorporated are maintained for longer periods [Kirn et al., 1991; Nottebohm et al., 1994]. Clearly, our knowledge of the phenotype of adult-generated neurons is still rudimentary, and particularly little is known about their function within the structures they populate. If new neurons undergo a change in the use of a particular neurotransmitter when they mature - as can be the case during development [Ganguly et al., 2001] - then even transient populations of new cells could significantly impact on circuit function. This, as well as determining how much of their final phenotype depends on intrinsic programming or extrinsic factors will be important if one is to harness these cells for therapeutic uses.

\section{Birth and Death}

In both birds and mammals, the ongoing recruitment of new neurons in adulthood is balanced by neuronal death [Kirn and Nottebohm, 1993; Kirn et al., 1994; Gould and Cameron, 1996; Petreanu and Alvarez-Buylla, 2000], leading to the idea that death might actually trigger birth. To directly test this hypothesis we selectively killed the majority of either the $\mathrm{HVC} \rightarrow \mathrm{RA}$ projecting neurons (which are normally undergoing replacement), or the $\mathrm{HVC} \rightarrow \mathrm{X}$ projecting cells (which normally do not die), in adult male zebra finches. Selectivity of this procedure is achieved by injection of nanospheres conjugated to the chromophore chlorin $e_{6}$ to retrogradely label the targeted neuron type. This drug is harmless to the neurons that carry it, unless activated by 674-nm laser illumination, which renders chlorin $e_{6}$ cytotoxic and induces the neurons to undergo apoptosis [Madison and Macklis, 1993; Sheen and Macklis, 1994]. Using this method in adult zebra finches established that neuronal recruitment can, indeed, be triggered by prior neuronal death, as shown by a substantial increase of $\left[{ }^{3} \mathrm{H}\right]$ thymidine-labeled $\mathrm{HVC} \rightarrow$ RA neurons after neuronal degeneration had been induced in this neuron type [Scharff et al., 2000] (fig. 4E). In fact, it appears that upregulation of neuronal recruitment after selective degeneration was able to replenish the entire contingent of lost neurons, as the total number of $\mathrm{HVC} \rightarrow \mathrm{RA}$ neurons three months after the selective injury was not different from intact controls. Also suggestive of a compensation for the induced brain damage was the observation that song production, which is critically dependent on $\mathrm{HVC} \rightarrow \mathrm{RA}$ neuron function, first deteriorated significantly after the selective killing of the $\mathrm{HVC} \rightarrow \mathrm{RA}$ neurons, but then recovered to various degrees in a number of birds.

Neurogenesis and Regeneration in Adult

Birds and Mammals
Equally important though is the finding that deathinduced upregulation of neuronal recruitment appears to be cell-type specific; only the neuron type that normally undergoes replacement responds to this treatment. When $\mathrm{HVC} \rightarrow \mathrm{X}$ neurons, which normally neither die nor get recruited, were experimentally targeted to die, no compensatory neuronal recruitment of any type occurred. Thus, as a first approximation, recruitment of new neurons into adult HVC does not seem to be simply a question of available slots, nor of a universal death-signal commanding new neurons to arrive. Why death of one neuron type, but not of another, can result in recruitment of new neurons in adulthood will be a challenge to address. A first clue could be that targeted degeneration of the $\mathrm{HVC} \rightarrow \mathrm{X}$ neurons in young zebra finches did result in increased incorporation of new $\mathrm{HVC} \rightarrow \mathrm{RA}$ neurons (fig. 4E). The discrepancy between juvenile and adult animals could be due to different amounts of target space or the molecular milieu of HVC after targeted death, such as the availability of growth factors [e.g., insulin-like growth factor II; Holzenberger et al., 1997].

Compensatory neurogenesis also occurs in sensory epithelia, including the olfactory epithelium in rodents which can be reconstituted after chemical ablation [for review, see Calof et al., 1998], the hair cells in the ears of birds which regenerate after chemical or noise injury [for review, see Cotanche, 1999; Smolders, 1999], the retina of postnatal chicken which regenerates in response to neurochemical lesions [for review, see Reh and Fisher, 2001], and in lizards after acetylpyridine-induced degeneration [Font et al., 1997]. Likewise, excitotoxic lesions in the adult mammalian hippocampus that result in the death of mature granule neurons effectively stimulate increased granule neuron recruitment [Gould and Tanapat, 1997], a process that requires FGF-2 [Yoshimura et al., 2001]. Such lesions do not succeed to the same extent in mouse cortex, where no new neurons are normally observed [Weinstein et al., 1996]. Yet, using the approach of targeted neuronal death (described above for songbirds) in mouse cortex, in which neurogenesis does not normally occur, Magavi et al. [2000] found a significant increase in the recruitment of new neurons to the site of injury. Moreover, some of them appeared to be connected to the appropriate target and survived for months. This result implies that even in mammals there is a dormant capacity for injured cortex to recruit and incorporate neurons in adulthood under the appropriate conditions. Similarly, injury-induced demyelination induced the generation of remyelinating oligodendrocytes [NaitOumesmar et al., 1999], with the SVZ probably being the source of those cells.

Brain Behav Evol 2001;58:306-322 
Elimination of the adult neuronal precursors themselves, rather than their mature differentiated progeny, also stimulates regeneration of the germinal region. When neuronal precursors in the SVZ are killed by infusion of the anti-mitotic drug Ara-C, (see section 'Glial Cells as Stem Cells in Adult Mice'), the SVZ regenerates robustly and rapidly to produce olfactory bulb interneurons [Doetsch et al., 1999a, b]. The subgranular layer of the hippocampal formation also regenerates the granule neurons of the dentate gyrus after elimination of precursors by a similar anti-mitotic protocol [Seri et al., 2001].

\section{Challenges for Brain Repair}

The conditions under which neuronal regeneration after experimentally induced cell death in mice and birds mentioned above takes place is instructive for two reasons: in all but one case [Magavi et al., 2000], the neurons regenerated were those produced under normal intact conditions; and in all cases, the type of cell death induced did not interfere with surrounding tissue or result in glial scarring.

These examples highlight the capacity of brains to repair themselves when mechanical (e.g., glial scarring) and molecular barriers are absent, both of which often impede regeneration after injury or disease. How to overcome these limitations and how to prompt cells of various provenance (either endogenous or transplanted) to assume the appropriate fates have been addressed recently in excellent review articles [Horner and Gage, 2000; Temple, 2001], and only a few pertinent points will be discussed here.

\section{Novel Fates}

Understanding the potential of different precursors to differentiate into neurons of diverse phenotypes, and how to manipulate that potential, are two of the many necessary steps towards successful brain repair. The surprising identification of SVZ astrocytes as stem cells raises the hopeful possibility that astrocytes throughout the brain may have neurogenic and/or stem cell potential given the appropriate prodding. In fact, stem cells can be cultured from areas throughout the brain [Palmer et al., 1995, 1999], but it is unknown whether these stem cells also correspond to astrocytes.

The capacity of postnatal and adult precursor cells to differentiate into neurons with a novel fate, or to differentiate into the same fate but in a different place, has been addressed by transplanting precursors from one area (or developmental stage) into other brain areas (or developmental stages). For the fate of a precursor to be maintained in an ectopic location, the host environment needs to be permissive for the cell to express its intrinsically specified fate. In contrast, for differentiation into a novel fate, the precursor must not yet be irreversibly committed and be able to respond to the local cues, including those that specify cell fate and cell migration [Jankovski and Sotelo, 1996].

The success of these kinds of studies has been mixed and depends on whether the transplanted cells are directly transplanted after dissection from the donor brain, or are first cultured in the presence of growth factors before transplantation. In addition, one should bear in mind that transplanted cells are not a homogeneous population, but typically consist of a mixture of progenitors and other cells rather than purified stem cells. Cells freshly isolated from the postnatal or adult SVZ and directly transplanted into other adult brain areas can continue to differentiate into their normal phenotype but stay close to the implantation site [Zigova et al., 1998; Herrera et al., 1999]. However, postnatal SVZ cells grafted into embryonic brains, which are presumably richer in neurogenic cues, can also integrate into other brain regions but as interneurons only [Lim et al., 1997]. Recent work suggests that neurogenic potential may be increased by co-injecting factors, such as noggin, that can override local inhibitory signals [Lim et al., 2000]. Activation of other neurogenic genes, such as neurogenin, may provide similar properties [Nieto et al., 2001; Sun et al., 2001].

Greater plasticity of cell fate is possible when cells are cultured first in the presence of growth factors before transplantation. Under these conditions, cells that are normally not neurogenic but gliogenic, such as precursors in the adult mammalian spinal cord, can give rise to neurons when transplanted into the dentate gyrus after culturing in basic fibroblast growth factor (bFGF) [Shihabuddin et al., 2000]. Cells from neurogenic regions also exhibit this plasticity: cultured cells from the dentate gyrus can give rise to olfactory bulb interneurons after transplantation into the olfactory bulb [Suhonen et al., 1996]. Whether these cells have the potential to do so without preculturing in the presence of growth factors needs to be evaluated. It is possible that growth factors cause the cells to dedifferentiate or become reprogrammed, which could allow greater flexibility in manipulation towards desired phenotypes. A promising example of this plasticity is the recent report that the conversion of $\mathrm{O} 2 \mathrm{~A}$ progenitors into astrocytic cells endows them with the novel potential to give rise to neurons [Kondo and Raff, 2000]. Besides 
being of potentially therapeutic value, this observation also re-emphasizes that a glial stage apparently precedes neurogenesis.

As an alternative to transplantation, endogenous precursors can be stimulated in vivo, using molecular factors that have proven mitogenic or to promote survival in vitro, such as EGF, bFGF, brain-derived neurotrophic factor (BDNF) and transforming growth factor alpha (TGF-a) [Craig et al., 1996; Kuhn et al., 1997; Tropepe et al., 1997; Fallon et al., 2000; Benraiss et al., 2001; Pencea et al., 2001b]. Intraventricular infusion of EGF seems to induce glial differentiation [Craig et al., 1996; Kuhn et al., 1997], mirroring the fate of neurospheres that are transplanted back into embryos after culturing in EGF [Winkler et al., 1998]. Interestingly, infusion of ephrins/Eph family members results in a twofold increase in the number of astrocytes in the adult SVZ [Conover et al., 2000]. Recent work has shown that intraventricular infusion or overproduction of BDNF by ependymal cells leads to an increased recruitment of new neurons into the striatum and other non-neurogenic brain regions. Whether this effect is on SVZ precursors or on other latent precursors remains to be determined. As more molecules are identified that control cell proliferation during development, their potential to control or promote proliferation of adult precursors is also being explored. The list of such molecules includes sonic hedgehog which has been shown to control proliferation of cerebellar granule cell precursors [Wechsler-Reya and Scott, 1999], Wnts [Smalley and Dale, 1999; Patapoutian and Reichardt, 2000], and pituitary adenylate cyclase activating polypeptide (PACAP) [DiCicco-Bloom et al., 1998]. Many of these factors are conserved across phylogeny, including insulin-like growth factor (IGF), which is selectively and strongly expressed in $\mathrm{HVC} \rightarrow \mathrm{RA}$ neurons of songbirds [Holzenberger et al., 1997] and enhances their post-birth in vitro differentiation [Jiang et al., 1998] and also promotes neurogenesis in mouse hippocampus [Aberg et al., 2000].

\section{Commitment States}

Given that molecular pathways of neuronal and glial differentiation are beginning to be elucidated, it should soon become feasible to control the differentiation of cells along a desired lineage. However, the attempt to customdesign neurons of a particular phenotype from an uncommitted stem cell by finding the correct differentiation factors might end up being more difficult than to identify and harvest the cells at a specific stage of differentiation. For example, the molecular characterization of the SVZ stem cells, transit amplifying cells, and committed neuro- blasts will allow identification of cell-type specific markers, thus leading to the ability to isolate each population by fluorescent-activated cell sorting using these markers. The potential fates of purified populations of cells can then be tested. This promises new and more defined sources to replace damaged brain tissue. In addition, characterization of the neuronal phenotype of transplanted neurons must go beyond the use of generic and not exclusively neuronal markers, such as $\mathrm{NeuN}$, and include electrophysiological and anatomical characterization. Ultimately, functional recovery is the gold standard of brain repair.

\section{Control of the Cell Cycle}

The ongoing cell division in adult germinal regions requires exquisite control to prevent unwanted proliferation or tumor formation. Although positive regulators of the cell cycle have been extensively studied, recent work has shown that cell cycle inhibitors also play an important role in controlling cell proliferation [for review, see Dyer and Cepko, 2001]. Intriguingly, cell cycle inhibitors are not only conserved across phylogeny, but are utilized by progenitor cells of different lineages, including cerebellum [Miyazawa et al., 2000], retina [Dyer and Cepko, 2000; Levine et al., 2000], SVZ [van Lookeren Campagne and Gill, 1998; Coskun and Luskin, 2001], and the inner ear [Lowenheim et al., 1999]. Two families of cyclin-dependent kinase inhibitors (the Cip/Kip and INK4 families) control progression through the G1-S phase of the cell cycle. Depending on the species, cyclin-dependent kinase inhibitors can regulate not only cell division, but also cell differentiation [Ohnuma et al., 1999]. Another important principle is that distinct cell cycle inhibitors may preferentially act on different progenitors within a lineage, which could provide a mechanism for expansion of one progenitor type over another. For example, in the retina, subsets of progenitor cells can be defined by expression of distinct cell cycle inhibitors [Dyer and Cepko, 2001]. Such a division of labor is likely also occurring in the postnatal and adult rodent SVZ. p27Kip-1 and p19Ink4 are expressed both in the SVZ and in the rostral migratory stream, where p19Ink4 occurs in an increasing gradient towards the olfactory bulb [van Lookeren Campagne and Gill, 1998; Coskun and Luskin, 2001]. Interestingly, p27Kip-1 appears to control proliferation of the transit amplifying cells [Doetsch et al., 2002], whereas p19Ink4 is more involved in controlling cell division of the migratory neuroblasts [Coskun and Luskin, 2001]. Such a hierarchical mode of cell cycle control is also found in the hematopoietic system, where $\mathrm{p} 27 \mathrm{Kip} 1$ acts at the transit amplify- 
ing stage [Cheng et al., 2000a] and p21Waf1 controls the cell cycle of more quiescent stem cells [Cheng et al., $2000 \mathrm{~b}]$. The findings that mutation of $\mathrm{p} 27 \mathrm{Kip} 1$ leads to division of normally quiescent cells in mammals in the inner ear [Lowenheim et al., 1999] and to reactive gliosis in the retina [Dyer and Cepko, 2000] hints that by up- or down-regulating cell cycle inhibitors it might eventually be possible to stimulate quiescent precursors and to prevent the damaging reactive gliosis that occurs after injury. Defining exactly which cell cycle inhibitors are expressed in different progenitors of distinct lineages will be critical to achieve this.

\section{Targeted Migration}

One of the limitations of cell replacement by endogenous precursors in adult mammals is their apparent unidirectional migration to the olfactory bulb. This could be overcome by redirecting the tangentially migrating stream of olfactory bulb-bound neurons wholesale into a different direction, perhaps by manipulation of chemorepellents which have been invoked in the migration along the rostral migratory stream [Hu, 1999] or chemoattractants, even though the olfactory bulb itself does not seem to be a source of such molecules [Jankovski et al., 1998; Kirschenbaum et al., 1999]. Alternatively, one could test whether those neurons could use radial glia as a substrate for migration and if so try to re-induce radial glia in adult mice. Towards the first end, mouse SVZ neural precursors could be transplanted into the adult bird VZ where radial glia are present throughout adulthood. Means of re-inducing radial glia in mammals are already being pursued. After laser-induced cell death in cortex, and transplantation of embryonic neurons into the lesion site, astrocytes lose their branched processes, transition to a more elongated morphology, and re-express the radial glial marker RC-2 [Leavitt et al., 1999]. Similarly, transplantation of embryonic cortical Cajal-Retzius cells into adult cerebellum results in induction of a radial glial phentoype in Bergmann glia [Soriano et al., 1997]. Although the factors underlying this transition have not been identified, it is likely that they are being secreted by the transplanted embryonic neurons. One candidate is neuregulin/GGF signalling through the erbB receptors, which are expressed by radial glia during development and are necessary for the maintenance of the radial glial phenotype [Anton et al., 1997]. In vitro studies have also identified a biochemical activity that causes astrocytes to adopt a radial glial morphology [Hunter and Hatten, 1995]. The plasticity of the radial glia-astrocyte switch is promising, but can induced radial glia support migration of neurons into oth- er brain regions and can this be achieved directionally? Can induced radial glia also act as neuronal precursors? And if so, does the regional heterogeneity they exhibit in development, e.g. Pax6 expression [Götz et al., 1998], determine which kind of neurons can be generated?

A principle insight we can draw from comparative analysis of adult neurogenesis in birds and mice is that glial cells are conserved as stem cells (or precursors) across phylogeny. It will be vital to elucidate the lineage tree of radial glia and their ultimate conversion into astrocytes, not only to cement the apparent relationship of stem cells in the embryo and in the adult, but also to understand the progressive restriction exhibited as they transform into astrocytes. Elegant tracing of lineage trees of multipotential stem cells from the cortex of the mouse embryo has revealed that stem cells undergo asymmetric divisions generating neurons and later switching to generating glia [Qian et al., 1998, 2000]. We can postulate that radial glia are the stem cells in these trees, generating daughter cells and ultimately, at the end of neurogenesis, differentiating into astrocytes. Over time, the diversity of neurons generated becomes increasingly limited to a few types in the adult. One might speculate that the greater neuronal diversity produced by adult birds is the result of the maintenance of a less committed (radial) glial phenotype, and that after the conversion to astrocytes (in mammals) fewer neuronal fates can be generated. Thus, cross-species molecular characterization of embryonic and adult stem cells promises to be a rich source of insight.

\section{Acknowledgments}

The authors would like to thank E. Buck and L. Zakhary for critical reading of the manuscript, and J. Hirsch and C. Reid for providing cat and monkey brains. The original research reviewed here was performed in strict adherence to institutional guidelines. We are very grateful for the stimulating environments of the Nottebohm, Alvarez-Buylla, and Dulac labs, where experiments reported here were conducted. C.S. is funded by the Whitehall Foundation and NIH grant R01MH63132, F.D. is a Junior Fellow of the Harvard University Society of Fellows and recipient of the William F. Milton Fund. 


\section{References}

Aberg, M.A.I., N.D. Aberg, H. Hedbacker, J. Oscarsson, and P.S. Eriksson (2000) Peripheral infusion of IGF-I selectively induces neurogenesis in the adult rat hippocampus. J. Neurosci., 20: 2896-2903.

Altman, J. (1963) Autoradiographic investigation of cell proliferation in the brains of rats and cats. Anat. Rec., 145: 573-591.

Altman, J. (1969) Autoradiographic and histological studies of postnatal neurogenesis. IV. Cell proliferation and migration in the anterior forebrain, with special reference to persisting neurogenesis in the olfactory bulb. J. Comp. Neurol., 137: 433-458.

Altman, J., and S.A. Bayer (1990a) Mosaic organization of the hippocampal neuroepithelium and the multiple germinal sources of dentate granule cells. J. Comp. Neurol., 301: 325-342.

Altman, J., and S.A. Bayer (1990b) Migration and distribution of two populations of hippocampal granule cell precursors during the perinatal and postnatal periods. J. Comp. Neurol., 301: 365 381.

Altman, J., and G.D. Das (1965) Autoradiographic and histological evidence of postnatal hippocampal neurogenesis in rats. J. Comp. Neurol., 124: 319-336.

Altman, J., and D.D. Gopal (1965) Post-natal origin of microneurones in the rat brain. Nature, 207: 953-956.

Alvarez-Buylla, A., and J.R. Kirn (1997) Birth, migration, incorporation, and death of vocal control neurons in adult songbirds. J. Neurobiol., 33: 585-601.

Alvarez-Buylla, A., and F. Nottebohm (1988) Migration of young neurons in adult avian brain Nature, 335: 353-354.

Alvarez-Buylla, A., J.M. García-Verdugo, A.S. Mateo, and H. Merchant-Larios (1998) Primary neural precursors and intermitotic nuclear migration in the ventricular zone of adult canaries. J. Neurosci., 18: 1020-1037.

Alvarez-Buylla, A., J.M. García-Verdugo, and A.D. Tramontin (2001) A unified hypothesis on the lineage of neural stem cells. Nat. Rev. Neurosci., 2: 287-293.

Alvarez-Buylla, A., C.-Y. Ling, and W.S. Yu (1994) Contribution of neurons born during embryonic juvenile and adult life to the brain of adult canaries: Regional specificity and delayed birth of neurons in the song control nuclei. J. Comp. Neurol., 347: 233-248.

Alvarez-Buylla, A., M. Theelen, and F. Nottebohm (1988) Mapping of radial glia and of a new cell type in adult canary brain. J. Neurosci., 8 . 2707-2712.

Alvarez-Buylla, A., M. Theelen, and F. Nottebohm (1990) Proliferation 'hot spots' in adult avian ventricular zone reveal radial cell division. Neuron, 5: 101-109.

Anton, E.S., M.A. Marchionni, K.-F. Lee, and P. Rakic (1997) Role of GGF/neuregulin signaling in interactions between migrating neurons and radial glia in the developing cerebral cortex. Development, 124: 3501-3510.
Barami, K., K. Iversen, H. Furneaux, and S.A. Goldman (1995) Hu protein as an early marker of neuronal phenotypic differentiation by subependymal zone cells of the adult songbird forebrain. J. Neurobiol., 28: 82-101.

Benraiss, A., E. Chmielnicki, K. Lerner, D. Roh, and S.A. Goldman (2001) Adenoviral brainderived neurotrophic factor induces both neostriatal and olfactory neuronal recruitment from endogenous progenitor cells in the adult forebrain. J. Neurosci., 21: 6718-6731.

Calaora, V., G. Chazal, P.J. Nielsen, G. Rougon, and H. Moreau (1996) mCD24 expression in the developing mouse brain and in zones of secondary neurogenesis in the adult. Neuroscience, 73: 581-594.

Calof, A.L., J.S. Mumm, P.C Rim, and J. Shou (1998) The neuronal stem cell of the olfactory epithelium. J. Neurobiol., 36: 190-205.

Cameron, H.A., C.S. Wooley, B.S McEwen, and E. Gould (1993) Differentiation of newly born neurons and glia in the dentate gyrus of the adult rat. Neuroscience, 56: 337-344.

Cayre, M., C. Strambi, P. Charpin, R. Augier, M.R. Meyer, J.S. Edwards, and A. Strambi (1996) Neurogenesis in adult insect mushroom bodies. J. Comp. Neurol., 371: 300-310.

Cheng, T., N. Rodrigues, D. Dombkowski, S. Stier, and D.T. Scadden (2000a) Stem cell repopulation efficiency but not pool size is governed by p27(kip1). Nat. Med., 6: 1235-1240.

Cheng, T., N. Rodrigues, H. Shen, Y. Yang, D. Dombkowski, M. Sykes, and D.T. Scadden (2000b) Hematopoetic stem cell quiescence maintained by $\mathrm{p} 21 \mathrm{cip1} /$ wafl. Science, 287: 1804-1808.

Chiasson BJ, V. Tropepe, C.M. Morshead, and D. van der Kooy (1999) Adult mammalian forebrain ependymal and subependymal cells demonstrate proliferative potential, but only subependymal cells have neural stem cell characteristics. J. Neurosci., 19: 4462-4471.

Conover, J.C., F. Doetsch, J.M. García-Verdugo, N.W. Gale, G.D. Yancopoulos, and A. Alvarez-Buylla (2000) Disruption of Eph/ephrin signaling affects migration and proliferation in the adult subventricular zone. Nat. Neurosci., 3: 1091-1097.

Coskun, V., and M.B. Luskin (2001) The expression pattern of the cell cycle inhibitor p19(INK4d) by progenitor cells of the rat embryonic telencephalon and neonatal anterior subventricular zone. J. Neurosci., 21: 3092-3103.

Cotanche, D.A. (1999) Structural recovery from sound and aminoglycoside damage in the avian cochlea. Audiol. Neurootol., 4: 271-285.

Cotsarelis, G., S-Z Cheng, G. Dong, T-T. Sun, and R.M. Lavkar (1989) Existence of slow cycling limbal epithelial basal cells that can be preferentially stimulated to proliferate: Implications on epithelial stem cells. Cell, 57: 201-209.

Craig, C.G., V. Tropepe, C.M. Morshead, B.A. Reynolds, S. Weiss, and D. Van der Kooy (1996) In vivo growth factor expansion of endogenous subependymal neural precursor cell populations in the adult mouse brain. J. Neurosci., 16: 2649-2658.
DiCicco-Bloom, E., N. Lu, J.E Pintar, and J. Zhang (1998) The PACAP ligand/receptor system regulates cerebral cortical neurogenesis. Ann. N.Y. Acad. Sci., 865: 274-289.

Doetsch, F., and A. Alvarez-Buylla (1996) Network of tangential pathways for neuronal migration in adult mammalian brain. Proc. Natl. Acad. Sci. USA, 93: 14895-14900.

Doetsch, F., I. Caille, D.A. Lim, J.M García-Verdugo, and A. Alvarez-Buylla (1999b) Subventricular zone astrocytes are neural stem cells in the adult mammalian brain. Cell, 97: 703716.

Doetsch, F., J.M. García-Verdugo, and A. AlvarezBuylla (1997) Cellular composition and threedimensional organization of the subventricular germinal zone in the adult mammalian brain. $\mathrm{J}$. Neurosci., 17: 5046-5061.

Doetsch, F., J.M. García-Verdugo, and A. AlvarezBuylla (1999a) Regeneration of a germinal layer in the adult mammalian brain. Proc. Natl. Acad. Sci. USA, 96: 11619-11624.

Doetsch, F., J.M. García-Verdugo, I. Caille, A. Alvarez-Buylla, M.V. Chao, and P. CasacciaBonnefil (2002) Lack of the cell cycle inhibitor p27Kipl results in selective increase of transit amplifying cells for adult neurogenesis. J. Neurosci., 22: 2246-2254.

Dutar, P., J.J. Pterozzino, H.M. Vu, M.F. Schmidt, and D.J. Perkel (2000) Slow synaptic inhibition mediated by metabotropic glutamate receptor activation of GIRK channels. J. Neurophysiol., 84: 2284-2290.

Dutar, P., H.M. Vu, and D.J. Perkel (1998) Multiple cell types distinguished by physiological, pharmacological, and anatomic properties in nucleus $\mathrm{HV}$ c of the adult zebra finch. J. Neurophysiol., 80: 1828-1838.

Dyer, M.A., and C.L. Cepko (2000) Control of Müller glial cell proliferation and activation following retinal injury. Nat. Neurosci., 3: 873880.

Dyer, M.A., and C.L. Cepko (2001) Regulating proliferation during retinal development. Nat. Rev. Neurosci., 2: 333-342.

Eckenhoff, M.F., and P. Rakic (1988) Nature and fate of proliferative cells in the hippocampal dentate gyrus during the life span of the Rhesus monkey. J. Neurosci., 8: 2729-2747.

Eriksson, P.S., E. Perfilieva, T. Björk-Eriksson, A.M. Alborn, C. Norborg, D.A. Peterson, and F.H. Gage (1998) Neurogenesis in the adult human hippocampus. Nat. Med., 4: 13131317.

Fallon, J., S. Reid, R. Kinyamu, I. Opole, R. Opole, J. Baratta, M. Korc, T.L. Endo, A. Duong, G. Nguyen, M. Karkehabadhi, D. Twardzik, and S. Loughlin (2000) In vivo induction of massive proliferation, directed migration, and differentiation of neural cells in the adult mammalian brain. Proc. Natl. Acad. Sci. USA, 97: 14686-14691.

Font, E., E. Desfilis, M. Perez-Cañellas, S. Alcantara, and J.M. García-Verdugo (1997) 3-Acetylpyridine-induced degeneration and regeneration in the adult lizard brain: A qualitative and quantitative analysis. Brain Res., 754: 245-259. 
Font, E., E. Desfilis, M.M. Pérez-Cañellas, and J.M. García-Verdugo (2001) Neurogenesis and neuronal regeneration in the adult reptilian brain. Brain Behav. Evol., 58: 276-295.

Frederiksen, K., and R.D.G. McKay (1988) Proliferation and differentiation of rat neuroepithelial precursor cells in vivo. J. Neurosci., 8 . 1144-1151

Gadisseux, J.F., P. Evrard, J.P. Misson, and V.S Caviness (1989) Dynamic structure of the radial glial fiber system of the developing murine cerebral wall: An immunocytochemical analysis. Dev. Brain Res., 50: 55-67.

Gage, F. (2000) Mammalian neural stem cells Science, 287: 1433-1438.

Gage, F., G. Kempermann, T.D. Palmer, D.A Peterson, and J. Ray (1998) Multipotent progenitor cells in the adult dentate gyrus. J. Neurobiol., 36: 249-266.

Gaiano, N., J.S. Nye, and G. Fishell (2000) Radial glial identity is promoted by Notch 1 signaling in the murine forebrain. Neuron, 26: 395-404.

Ganguly, K., A.F. Schinder, S.T. Wong, and M Poo (2001) GABA itself promotes the developmental switch of neuronal GABAergic responses from excitation to inhibition. Cell, 105: 521-532

García-Verdugo, J.-M., F. Doetsch, H. Wichterle, D.A. Lim, and A. Alvarez-Buylla (1998) Architecture and cell types of the adult subventricular zone: In search of the stem cells. J. Neurobiol., 36: 234-248.

Ghooray, G.T., and G.F. Martin (1993) Development of radial glia and astrocytes in the spinal cord of the North American opossum (Didelphis virginiana): An immunohistochemical study using anti-vimentin and anti-glial fibrillary acidic protein. Glia, 9: 1-9.

Goldman, S.A. (1998) Adult neurogenesis: From canaries to the clinic. J. Neurobiol., 36: 267286.

Goldman, S.A., and F. Nottebohm (1983) Neuronal production, migration, and differentiation in a vocal control nucleus of the adult female canary brain. Proc. Natl. Acad. Sci. USA, 80 2390-2394.

Goldman, S.A., A. Zukhar, K. Barami, T. Mikawa, and D. Niedzwiecki (1996) Ependymal/subependymal zone cells of postnatal and adult songbird brain generate both neurons and nonneuronal siblings in vitro and in vivo. J. Neurobiol., 30: 505-520.

Götz, M., A. Stoykova, and P. Gruss (1998) Pax6 controls radial glia differentiation in the cerebral cortex. Neuron, 21: 1031-1044.

Gould, E., and H.A. Cameron (1996) Regulation of neuronal birth, migration and death in the rat dentate gyrus. Dev. Neurosci., 18: 22-35.

Gould, E., and P. Tanapat (1997) Lesion-induced proliferation of neuronal progenitors in the dentate gyrus of the adult rat. Neuroscience, 80: 427-436.

Gould, E., A. Beylin, P. Tanapat, A. Reeves, and T.J. Shors (1999c) Learning enhances adult neurogenesis in the hippocampal formation. Nat. Neurosci., 2: 203-205.
Gould, E., B.S. McEwen, P. Tanapat, L.A.M. Galea, and E. Fuchs (1997) Neurogenesis in the dentate gyrus of the adult tree shrew is regulated by psychosocial stress and NMDA receptor activation. J. Neurosci., 17: 2492-2498.

Gould, E., A.J. Reeves, M. Fallah, P. Tanapat, C.G. Gross, and E. Fuchs (1999a) Hippocampal neurogenesis in adult Old World primates. Proc. Natl. Acad. Sci. USA, 96: 5263-5267.

Gould, E., A.J. Reeves, M.S.A. Graziano, and C.G. Gross (1999b) Neurogenesis in the neocortex of adult primates. Science, 286: 548-552.

Gray, G.E., and J.R. Sanes (1992) Lineage of radial glia in the chicken optic tectum. Development, 114: 271-283.

Gray, G.E., J.C. Clover, J. Majors, and J.R. Sanes (1988) Radial arrangement of clonally related cells in the chicken optic tectum: Lineage analysis with a recombinant retrovirus. Proc. Natl. Acad. Sci. USA, 85: 7356-7360.

Gray, G.E., S.M. Leber, and J.R. Sanes (1990) Migratory patterns of clonally related cells in the developing central nervous system. Experientia, 46: 929-940.

Gritti, A., P. Frolichsthal-Schoeller, R. Galli, E.A. Parati, L. Cova, S.F. Pagano, C.R. Bjornson, and A.L. Vescovi (1999) Epidermal and fibroblast growth factors behave as mitogenic regulators for a single multipotent stem cell-like population from the subventricular region of the adult mouse forebrain. J. Neurosci., 19: 3287-3297.

Gritti, A., E.A. Parati, L. Cova, P. Frolichsthal, R. Galii, E. Wanke, L. Faravelli, D.J. Morassutti, F. Roisen, D.D. Nickel, and A.I. Vescovi (1996) Multipotential stem cells from the adult mouse brain proliferate and self-renew in response to basic fibroblast growth factor. J. Neurosci., 16: 1091-1100.

Gross, C.G. (2000) Neurogenesis in the adult brain: Death of a dogma. Nat. Rev. Neurosci., 1: 6773.

Hartfuss, E., R. Galli, N. Heintz, and M. Götz (2001) Characterization of CNS precursor subtypes and radial glia. Dev. Biol., 229: 15-30.

Hatten, M.E. (1993) The role of migration in central nervous system neuronal development. Curr. Opin. Neurobiol., 3: 38-44.

Hatten, M.E., and C.A. Mason (1990) Mechanism of glial-guided neuronal migration in vitro and in vivo. Experientia, 46: 907-916.

Herrera, D.G., J.M. García-Verdugo, and A. Alvarez-Buylla (1999) Adult-derived neural precursors transplanted into multiple regions in the adult brain. Ann. Neurol., 46: 867-877.

Holland, E.C., and H.E. Varmus (1998) Basic fibroblast growth factor induces cell migration and proliferation after glia-specific gene transfer in mice. Proc. Natl. Acad. Sci. USA, 95: 12181223.

Holzenberger, M., E.D. Jarvis, C. Chong, M. Grossman, F. Nottebohm, and C. Scharff (1997) Selective expression of insulin-like growth factor II in the songbird brain. J. Neurosci., 7: 6974-6987.

Horner, P.J., and F.H. Gage (2000) Regenerating the damaged central nervous system. Nature, 407: $963-970$
Hu, H. (1999) Chemorepulsion of neuronal migration by Slit 2 in the developing mammalian forebrain. Neuron, 23: 703-711.

Hunter, K.E., and M.E. Hatten (1995) Radial glial cell transformation to astrocytes is bidirectional: Regulation by a diffusible factor in embryonic forebrain. Proc. Natl. Acad. Sci. USA, 92: 2061-2065.

Jacobson, M. (1991) Developmental Neurobiology. Plenum Press, New York.

Jankovski, A., and C. Sotelo (1996) Subventricular zone-olfactory bulb migratory pathway in the adult mouse: Cellular composition and specificity as determined by heterochronic and heterotopic transplantation. J. Comp. Neurol., 371 : 376-396.

Jankovski, A., C. Garcia, E. Soriano, and C. Sotelo (1998) Proliferation, migration and differentiation of neuronal progenitor cells in the adult mouse subventricular zone surgically separated from its olfactory bulb. Eur. J. Neurosci., 10 : 3853-3868.

Jiang, J., J. McMurty, D. Niedwiecki, and S.A. Goldman (1998) Insulin-like growth factor-1 is a radial cell-associated neurotrophin that promotes neuronal recruitment from the adult songbird ependyma/subependyma. J. Neurobiol., 36: 1-15.

Johansson, C.B., S. Momma, D.L. Clarke, M. Risling, U. Lendahl, and J. Frisén (1999) Identification of a neural stem cell in the adult mammalian central nervous system. Cell, 96: 2534

Kaplan, M.S. (1981) Neurogenesis in the 3-monthold rat visual cortex. J. Comp. Neurol., 195. 323-338.

Kirn, J.R., and F. Nottebohm (1993) Direct evidence for loss and replacement of projection neurons in adult canary brain. J. Neurosci., 13: 1654-1663.

Kirn, J.R., A. Alvarez-Buylla, and F. Nottebohm (1991) Production and survival of projection neurons in the high vocal center of adult male canaries. J. Neurosci., 11: 1756-1762.

Kirn, J.R., Y. Fishman, K. Sasportas, A. AlvarezBuylla, and F. Nottebohm (1999) Fate of new neurons in adult canary high vocal center during the first 30 days after their formation. J. Comp. Neurol., 411: 487-494.

Kirn, J., B. O'Loughlin, S. Kasparian, and F. Nottebohm (1994) Cell death and neuronal recruitment in the high vocal center of adult male canaries are temporally related to changes in song. Proc. Natl. Acad. Sci. USA, 91: 78447848 .

Kirschenbaum, B., F. Doetsch, C. Lois, and A. Alvarez-Buylla (1999) Adult subventricular zone neuronal precursors continue to proliferate and migrate in the absence of the olfactory bulb. J. Neurosci., 19: 2171-2180.

Kondo, T., and M. Raff (2000) Oligodendrocyte precursor cells reprogrammed to become multipotential CNS stem cells. Science, 289: 17541757.

Kornack, D.R., and P. Rakic (1999) Continuation of neurogenesis in the hippocampus of the adult macaque monkey. Proc. Natl. Acad. Sci. USA, 96: 5768-5773. 
Kornack, D.R., and P. Rakic (2001) The generation, migration, and differentiation of olfactory neurons in the adult primate brain. Proc. Natl. Acad. Sci. USA, 98: 4752-4757.

Kornack, D.R. and P. Rakic (2001b) Cell proliferation without neurogenesis in adult primate neocortex. Science, 294: 2127-2130.

Kubota, M., and I. Taniguchi (1998) Electrophysiological characteristics of classes of neurons in the HVc of the zebra finch. J. Neurophysiol., 80: 914-923.

Kuhn, H.G., J. Winkler, G. Kempermann, L.J. Thal, and F.H. Gage (1997) Epidermal growth factor and fibroblast growth factor-2 have different effects on neural progenitors in the adult rat brain. J. Neurosci., 17: 5820-5829.

Laywell, E.D., P. Rakic, V.G. Kukekov, E.C. Holland, and D.A. Steindler (2000) Identification of a multipotent astrocytic stem cell in the immature and adult mouse brain. Proc. Natl. Acad. Sci. USA, 97: 13883-13888.

Leavitt, B.R., C.S. Hernit-Grant, and J.D. Macklis (1999) Mature astrocytes transform into transitional radial glia within adult mouse neocortex that supports directed migration of transplanted immature neurons. Exp. Neurol., 157: 43-57.

Levine, E.M., J. Close, M. Fero, A. Ostrovsky, and T.A. Reh (2000) p27 regulates cell cycle withdrawal of late multipotent progenitor cells in the mammalian retina. Dev. Biol., 219: 299-314.

Levison, S.W., and J.E. Goldman (1993) Both oligodendrocytes and astrocytes develop from progenitors in the subventricular zone of postnatal rat forebrain. Neuron, 10: 201-212.

Levitt, P.R., M.L.Cooper, and P. Rakic (1981) Coexistence of neuronal and glial precursor cells in the cerebral ventricular zone of the fetal monkey: An ultrastructural immunoperoxidase analysis. J. Neurosci., 1: 27-39.

Lim, D.A., G.J. Fishell, and A. Alvarez-Buylla (1997) Postnatal mouse subventricular zone neuronal precursors can migrate and differentiate within multiple levels of the developing neuraxis. Proc. Natl. Acad. Sci. USA, 94. 14832-14836.

Lim, D.A., A.D. Tramontin, J.M. Trevejo, D.G. Herrera, J.M. García-Verdugo, and A. AlvarezBuylla (2000) Noggin antagonizes BMP signaling to create a niche for adult neurogenesis. Neuron, 28: 713-726.

Liu, X.S., S. Tilwalli, G. Ye, P.A. Lio, J.F. Pasternak, and B.L. Trommer (2000) Morphologic and electrophysiologic maturation in developing dentate gyrus granule cells. Brain Res., 856 202-212.

Lois, C., and A. Alvarez-Buylla (1994) Long-distance neuronal migration in the adult mammalian brain. Science, 264: 1145-1148.

Lois, C., J.M. García-Verdugo, and A. AlvarezBuylla (1996) Chain migration of neuronal precursors. Science, 271: 978-981.

Lowenheim, H., D.N. Furness, J. Kil, C. Zinn, K. Gultig, M.L. Fero, D. Frost, A.W. Gummer, J.M. Roberts, E.W. Rubel, C.M. Hackney, and H.P. Zenner (1999) Gene disruption of p27(Kip1) allows cell proliferation in the postnatal and adult organ of Corti. Proc. Natl Acad. Sci. USA, 96: 4084-4088.
Luskin, M.B. (1993) Restricted proliferation and migration of postnatally generated neurons derived from the forebrain subventricular zone. Neuron, 11: 173-189.

Madison, R., and J.D. Macklis (1993) Noninvasively induced degeneration of neocortical pyramidal neurons in vivo: Selective targeting by laser activation of retrogradely transported photolytic chromophore. Exp. Neurol., 121: 153-159.

Magavi, S.S., B.R. Leavitt, and J.D. Macklis (2000) Induction of neurogenesis in the neocortex of adult mice. Nature, 405: 951-955.

Malatesta, P., E. Hartfuss, and M. Götz (2000) Isolation of radial glial cells by fluorescent-activated cell sorting reveals a neuronal lineage. Development, 127: 5253-5263.

Marcus, R.C., C.L. Delaney, and S.S. Easter (1999) Neurogenesis in the visual system of embryonic and adult zebrafish (Danio rerio). Vis. Neurosci., 16: 417-424.

Markakis, E.A., and F. Gage (1999) Adult-generated neurons in the dentate gyrus send axonal projections to field CA 3 and are surrounded by synaptic vesicles. J. Comp. Neurol., 406: 449460.

Miyata, T., A. Kawaguchi, H. Okano, and M. Ogawa (2001) Asymmetric inheritance of radial glial fibers by cortical neurons. Neuron, 31: 727-741.

Miyazawa, K., T. Himi, V. Garcia, H. Yamagishi, S. Sato, and Y. Ishizaki (2000) A role for p27/ Kip1 in the control of cerebellar granule cell precursor proliferation. J. Neurosci., 20: 57565763.

Morest, D.K. (1970) A study of neurogenesis in the forebrain of opossum pouch young. Z. Anat. Entwicklungsgesch., 130: 265-305.

Morshead, C.M., and D. Van der Kooy (1992) Postmitotic death is the fate of constitutively proliferating cells in the subependymal layer of the adult mouse brain. J. Neurosci., 12: 249256.

Morshead, C.M., and D. Van der Kooy (2001) A new 'spin' on neural stem cells? Curr. Opin. Neurobiol., 11: 59-65.

Morshead, C.M., B.A. Reynolds, C.G. Craig, M.W. McBurney, W.A. Staines, D. Morassutti, S. Weiss, and D. Van der Kooy (1994) Neural stem cells in the adult mammalian forebrain: A relatively quiescent subpopulation of subependymal cells. Neuron, 13: 1071-1082.

Nadarajah, B, J.E. Brunstrom, J. Grutzendler, R.O. Wong, and A.L. Pearlman (2001) Two modes of radial migration in early development of the cerebral cortex. Nat. Neurosci., 4: 143-150.

Nait-Oumesmar, B., L. Decker, F. Lachapelle, V. Avellana-Adalid, C. Bachelin, and A.B. Van Evercooren (1999) Progenitor cells of the adult mouse subventricular zone proliferate, migrate and differentiate into oligodendrocytes after demyelination. Eur. J. Neurosci., 11: 43574366.

Nieto, M., C. Schuurmans, O. Britz, and F. Guillemot (2001) Neural bHLH genes control the neuronal versus glial fate decision in cortical progenitors. Neuron, 29: 401-413.
Noctor, S.C., A.C. Flint, T.A. Weissmann, R.S Dammerman, and A.R. Kriegstein (2001) Neurons derived from radial cells establish radial units in neocortex. Nature, 109: 714-720.

Nottebohm, F., B. O'Loughlin, K. Gould, K. Yohay, and A. Alvarez-Buylla (1994) The life span of new neurons in a song control nucleus of the adult canary brain depends on time of year when these cells are born. Proc. Natl. Acad. Sci. USA, 91: 7849-7853.

Nowakowski, R.S., and N.L. Hayes (2000) New neurons: Extraordinary evidence or extraordinary conclusion? Science, 288: 771a.

Ohnuma, S., A. Philpott, K. Wang, C.E. Holt, and W.A. Harris (1999) p27Xic1, a Cdk inhibitor, promotes the determination of glial cells in Xenopus retina. Cell, 99: 499-510.

Palmer T.D., E.A. Markakis, A.R. Willhoite, F. Safar, and F.H. Gage (1999) Fibroblast growth factor-2 activates a latent neurogenic program in neural stem cells from diverse regions of the adult CNS. J. Neurosci., 19: 8487-8497.

Palmer T.D., J. Ray, and F.H. Gage (1995) FGF2-responsive neuronal progenitors reside in proliferative and quiescent regions of the adult rodent brain. Mol. Cell. Neurosci., 6: 74-86.

Parnavelas, J. (2000) The origin and migration of cortical neurones: New vistas. Trends Neurosci., 23: 126-131.

Patapoutian, A., and L.F. Reichardt (2000) Roles of Wnt proteins in neural development and maintenance. Curr. Opin. Neurobiol., 10: 392 399.

Paton, J.A., G.D. Burd, and F. Nottebohm (1986) New neurons in an adult brain: Plasticity in an auditory-motor nucleus. In The Biology of Change in Otolaryngology (ed. by R.W. Ruben, T.R. van der Water and E.W. Rubel), Elsevier Biomed., Amsterdam, pp. 201-210.

Pencea V., K.D. Bingaman, L.J. Freedman, and M.B. Luskin (2001a) Neurogenesis in the subventricular zone and rostral migratory stream of the neonatal and adult primate forebrain. Exp. Neurol., 172: 1-16.

Pencea, V., K.D. Bingaman, S.J. Wiegand, and M.B. Luskin (2001b) Infusion of brain-derived neurotrophic factor into the lateral ventricle of the adult rat leads to new neurons in the parenchyma of the striatum, septum, thalamus, and hypothalamus. J. Neurosci., 21: 706-717.

Peretto, P., A. Merighi, A. Fasolo, and L. Bonfanti (1997) Glial tubes in the rostral migratory stream of the adult rat. Brain Res. Bull., 42: 921.

Petreanu, L.T., and A. Alvarez-Buylla (2000) An early wave of cell death of newly generated granule neurons in the adult mouse olfactory bulb. Soc. Neurosci. Abstr., 26: 1610.

Polenov, A.L., and V.K. Chetverukhin (1993) Ultrastructural radioautographic analysis of neurogenesis in the hypothalamus of the adult frog, Rana temporaria, with special reference to physiological regeneration of the preoptic nucleus. II. Types of neuronal cells produced. Cell Tiss. Res., 271: 351-362.

Potten, C.S., and R.J. Morris (1988) Epithelial stem cells in vivo. J. Cell Sci., 10: 45-62. 
Privat, A., and C.P. Leblond (1972) The subependymal layer and neighboring region in the brain of the young rat. J. Comp. Neurol., 146 . 277-302.

Qian, X., S.K. Goderie, Q. Shen, J.H. Stern, and S. Temple (1998) Intrinsic programs of patterned cell lineages in isolated vertebrate CNS ventricular zone cells. Development, 125: 31433152.

Qian, X., Q. Shen, S.K. Goderie, W. He, A. Capela, A.A. Davis, and S. Temple (2000) Timing of CNS cell generation: A programmed sequence of neuron and glial cell production from isolated murine cortical stem cells. Neuron, 28 . 69-80.

Rakic, P. (1972) Mode of cell migration to the superficial layers of fetal monkey neocortex. J. Comp. Neurol., 145: 61-84.

Rakic, P. (1985) Limits of neurogenesis in primates. Science, 227: 1054-1056.

Rakic, P. (1988) Specification of cerebral cortical areas. Science, 241: 170-176.

Rakic, P. (1995) Radial versus tangential migration of neuronal clones in the developing cerebral cortex. Proc. Natl. Acad. Sci. USA, 92: 11323 11327.

Reh, T.A., and A.J. Fischer (2001) Stem cells in the vertebrate retina. Brain Behav. Evol., 58: 296305

Reynolds, B., and S. Weiss (1992) Generation of neurons and astrocytes from isolated cells of the adult mammalian central nervous system. Science, 255: 1707-1710.

Rietze, R., P. Poulin, and S. Weiss (2000) Mitotically active cells that generate neurons and astrocytes are present in multiple regions of the adult mouse hippocampus. J. Comp Neurol., 424: 397-408.

Rietze, R.L., H. Valcanis, G.F. Brooker, T. Thomas, A.K. Voss, and P.F. Bartlett (2001) Purification of a pluripotent neural stem cell from the adult mouse brain. Nature, 412: 736-739.

Scharff, C., J.M. García-Verdugo, F. Doetsch, M. Grossman, A. Mateo, F. Nottebohm, and A. Alvarez-Buylla (1998) Large network of tangential pathways for chain migration in adult songbirds. Soc. Neurosci. Abstr., 24: 1189.

Scharff, C., J.R Kirn, M.R. Grossmann, J.D. Macklis, and F. Nottebohm (2000) Targeted neuronal death affects neuronal replacement and vocal behavior in adult songbirds. Neuron, 25 . 481-492.

Schmechel, D.E., and P. Rakic (1979a) A Golgi study of radial glia cells in developing monkey telencephalon: Morphogenesis and transformation into astrocytes. Anat. Embryol., 156: 115152.

Schmechel, D.E., and P. Rakic (1979b) Arrested proliferation of radial glial cells during midgestation in rhesus monkey. Nature, 277: 303 305.
Schmidt, M., and S. Harzsch (2000) Comparative analysis of neurogenesis in the central olfactory pathway of adult decapod crustaceans by in vivo BrdU labeling. Biol. Bull., 196: 127-136.

Seri, B., J.M. García-Verdugo, B.S. McEwen, and A. Alvarez-Buylla (2001) Astrocytes give rise to new neurons in the adult mammalian hippocampus. J. Neurosci., 21: 7153-7160.

Sheen, V.L., and J.D. Macklis (1994) Apoptotic mechanisms in targeted neuronal cell death by chromophore-activated photolysis. Exp. Neurol., 130: 67-81.

Shihabuddin, L.S., P.J. Horner, J. Ray, and F.H. Gage (2000) Adult spinal cord stem cells generate neurons after transplantation in the adult dentate gyrus. J. Neurosci., 20: 8727-8735.

Skogh, C., C. Eriksson, M. Kokaia, X.C. Meijer, L.U. Wahlberg, K. Wictorin, and K. Campbell (2001) Generation of regionally specified neurons in expanded glial cultures derived from the mouse and human lateral ganglionic eminence. Mol. Cell. Neurosci., 17: 811-820.

Smalley, M.J., and T.C. Dale (1999) Wnt signalling in mammalian development and cancer. Canc. Metast. Rev., 18: 215-230.

Smart, I. (1961) The subependymal layer of the mouse brain and its cell production as shown by radioautography after thymidine-H3 injection. J. Comp. Neurol., 116: 325-348.

Smolders, J.W. (1999) Functional recovery in the avian ear after hair cell regeneration. Audiol. Neurootol., 4: 286-302.

Soriano, E., R.M. Alvarado-Mallart, N. Dumesnil, J.A. Del Rio, and C. Sotelo (1997) Cajal-Retzius cells regulate the radial glia phenotype in the adult and developing cerebellum and alter granule cell migration. Neuron, 18: 563-577.

Sprangrude, G.J., S. Heimfeld, and I.L. Weissman (1988) Purification and characterization of mouse hematopoetic stem cells. Science, 241: $58-72$.

Stanfield, B.B., and J.E. Trice (1988) Evidence that granule cells generated in the dentate gyrus of adult rats extend axonal projections. Exp. Brain Res., 72: 399-406.

Suhonen, J.O., D.A. Peterson, J. Ray, and F.H. Gage (1996) Differentiation of adult hippocampus-derived progenitors into olfactory neurons in vivo. Nature, 383: 624-627.

Sun, Y., M. Nadal-Vicens, S. Misono, M.Z. Lin, A. Zubiaga, X. Hua, G. Fan, and M.E. Greenberg (2001) Neurogenin promotes neurogenesis and inhibits glial differentiation by independent mechanisms. Cell, 104: 365-376.

Temple, S. (2001) Stem cell plasticity: Building the brain of our dreams. Nat. Rev. Neurosci., 2: $513-520$
Tropepe, V., Craig, C.G., C.M. Morshead, and D. Van der Kooy (1997) Transforming growth factor-alpha null and senescent mice show decreased neural progenitor cell proliferation in the forebrain subependyma. J. Neurosci., 17 : 7850-7859.

van Lookeren Campagne, M., and R. Gill (1998) Tumor-suppressor p53 is expressed in proliferating and newly formed neurons of the embryonic and postnatal rat brain: Comparison with expression of the cell cycle regulators p21 Waf1/Cip1, p27Kip1, p57Kip2, p16Ink4a, cyclin G1, and the proto-oncogene Bax. J. Comp. Neurol., 397: 181-198.

Voigt, T. (1989) Development of glial cells in the cerebral wall of ferrets: Direct tracing of their transformation from radial glia into astrocytes. J. Comp. Neurol., 289: 74-88.

Wang, S., B.W. Scott, and M. Wojtowicz (2000) Heterogenous properties of dentate granule neurons in the adult rat. J. Neurobiol., 42: 248257.

Wechsler-Reya, R.J., and M.P. Scott (1999) Control of neuronal precursor proliferation in the cerebellum by Sonic Hedgehog. Neuron, 22 . 103-114.

Weinstein, D.E., P. Burrola, and T.J. Kilpatrick (1996) Increased proliferation of precursor cells in the adult rat brain after targeted lesioning. Brain Res., 743: 11-16.

Weiss, S., C. Dunne, J. Hewson, C. Wohl, M. Wheatley, A.C. Peterson, and B.A. Reynolds (1996) Multipotent CNS stem cells are present in the adult mammalian spinal cord and ventricular neuroaxis. J. Neurosci., 16: 75997609 .

Wichterle, H., J.M. García-Verdugo, and A. Alvarez-Buylla (1997) Direct evidence for homotypic, glia-independent neuronal migration. Neuron, 18: 779-791.

Winkler, C., R.A. Fricker, M.A. Gates, M. Olsson, J.P. Hammang, M.K. Carpenter, and A. Björklund (1998) Incorporation and glial differentiation of mouse EGF-responsive neural progenitor cells after transplantation into the embryonic rat brain. Mol. Cell. Neurosci., 11: 99_ 116.

Yoshimura, S., Y. Takagi, J. Harada, T. Teramoto, S.S. Thomas, C. Waeber, J.C. Bakowska, X.O Breakefield, and M.A. Moskowitz (2001) FGF2 regulation of neurogenesis in adult hippocampus after brain injury. Proc. Natl. Acad. Sci. USA, 98: 5874-5879.

Zigova, T., V. Pencea, R. Betarbet, S.J. Wiegand, C. Alexander, R.A. Bakay, and M.B. Luskin (1998) Neuronal progenitor cells of the neonatal subventricular zone differentiate and disperse following transplantation into the adult rat striatum. Cell Transplant., 7: 137-156.

Zupanc, G.K.H. (2001) Adult neurogenesis and neuronal regeneration in the central nervous system of teleost fish. Brain Behav. Evol., 58 . 250-275. 